\title{
Global habitat preferences of commercially valuable tuna
}

\author{
Haritz Arrizabalaga ${ }^{a, *}$, Florence Dufour ${ }^{b}$, Laurence Kell ${ }^{c}$, Gorka Merino ${ }^{a}$, Leire Ibaibarriaga ${ }^{d}$, \\ Guillem Chust ${ }^{d}$, Xabier Irigoien ${ }^{e}$, Josu Santiago ${ }^{d}$, Hilario Murua ${ }^{a}$, Igaratza Fraile ${ }^{a}$, Marina Chifflet ${ }^{a}$, \\ Nerea Goikoetxea ${ }^{d}$, Yolanda Sagarminaga ${ }^{a}$, Olivier Aumont ${ }^{f}$, Laurent Bopp ${ }^{g}$, Miguel Herrera ${ }^{h}$, \\ Jean Marc Fromentin', Sylvain Bonhomeau
}

\footnotetext{
${ }^{a}$ AZTI-Tecnalia, Marine Research Division, Herrera Kaia Portualdea z/g, 20110, Pasaia, Basque Country, Spain

${ }^{\mathrm{b}}$ NALDEO -55 rue de la villette. F-69425 Lyon cedex 03, France

c ICCAT Secretariat, Corazón de María 8, 28002Madrid, Spain

${ }^{d}$ AZTI-Tecnalia, Marine Research Unit, Txatxarramendi Ugartea z/g, 48395 Sukarrieta, Basque Country, Spain

e Red Sea Research Center, King Abdullah University of Science and Technology, Thuwal 23955-6900, Saudi Arabia

${ }^{f}$ Laboratoire d'Océanographie et du Climat: Expérimentations et Approches Numériques (LOCEAN), Centre IRD de Bretagne, F-29280 Plouzané, France

${ }^{g}$ Laboratoire des Sciences du Climat et de I'Environnement, UMR CEA-CNRS, CEA Saclay, F-91191 Gif-surYvette, France

h IOTC Secretariat PO Box 1011Victoria Seychelles

' Ifremer, UMR 212 EME, boulevard Jean Monnet, BP 171, Sete Cedex, 34203, France
}

\author{
*: Corresponding author : Haritz Arrizabalaga, tel.: +34 667174477 ; fax: +34 946572555 ; \\ email address : harri@azti.es
}

\begin{abstract}
:
In spite of its pivotal role in future implementations of the Ecosystem Approach to Fisheries Management, current knowledge about tuna habitat preferences remains fragmented and heterogeneous, because it relies mainly on regional or local studies that have used a variety of approaches making them difficult to combine. Therefore in this study we analyse data from six tuna species in the Pacific, Atlantic and Indian Oceans in order to provide a global, comparative perspective of habitat preferences. These data are longline catch per unit effort from 1958 to2007 for albacore, Atlantic bluefin, southern bluefin, bigeye, yellowfin and skipjack tunas. Both quotient analysis and Generalized Additive Models were used to determine habitat preference with respect to eight biotic and abiotic variables. Results confirmed that, compared to temperate tunas, tropical tunas prefer warm, anoxic, stratified waters. Atlantic and southern bluefin tuna prefer higher concentrations of chlorophyll than the rest. The two species also tolerate most extreme sea surface height anomalies and highest mixed layer depths. In general, Atlantic bluefin tuna tolerates the widest range of environmental conditions. An assessment of the most important variables determining fish habitat is also provided.
\end{abstract}

Keywords : Habitat ; Tuna fisheries ; Catch/ effort ; Environmental conditions ; Quotient analysis ; Generalized Additive Models ; Ecosystem Approach to Fisheries Management 


\section{Introduction}

Tunas are oceanic top predators that play an important role in marine ecosystems, account for nearly $20 \%$ of the value of marine capture fisheries and contribute to meeting worldwide protein requirements (FAO, 2011). The most economically important tuna species are the temperate tunas albacore (Thunnus alalunga), Atlantic bluefin tuna (Thunnus thynnus) and southern bluefin tuna (Thunnus maccoyii) and the tropical tunas yellowfin tuna (Thunnus albacares), bigeye tuna (Thunnus obesus) and skipjack tuna (Katsuwonus pelamis). Tunas migrate long distances during their life cycle, and are widely distributed over the Atlantic, Indian and Pacific Oceans. There is a single population for southern bluefin tuna inhabiting the southern ocean, and typically one or two populations of tropical and temperate tunas per ocean basin, except for albacore that has 3 populations in the Atlantic (Albaina et al., 2013). Tuna stocks are managed by 5 Tuna Regional Fishery Management Organizations (TRFMOs) with the primary objective of maintaining the productivity of each stock at its maximum, although in recent years there have been efforts towards the implementation of the Ecosystem Approach to Fisheries Management (EAFM).

Biotic and abiotic environmental variables affect tuna distribution and abundance (Lehodey et al., 1997, Ravier and Fromentin, 2004 and Sund et al., 1981). Characterising tuna habitat is thus 
essential to understand tuna spatio-temporal distribution and variability. This helps in interpretation of commercial fishery data, such as time series of catch per unit effort (CPUE) used in stock assessments to develop management advice (e.g. on Total Allowable Catches). Improved knowledge about tuna habitat and spatial distribution also allows spatial and temporal management measures to be considered, e.g. for by-catch mitigation while maintaining the profitability of fisheries (Hobday and Hartman, 2006; Hobday et al., 2011; Teo and Block, 2010).

Local habitat studies allow local problems, i.e. for specific fleets and individual TRFMOs, to be addressed. In contrast, global habitat studies covering the worldwide distribution of all tunas are required to address global management issues and facilitate the integration of EAFM in a consistent way across TRFMOs. For instance, in the short term, global habitat studies are required to determine optimum placements for large oceanic marine protected areas (Kaplan et al., 2013; Pala, 2013) based on hotspots of biodiversity and/or abundance (Worm et al., 2005). In the longer term, anthropogenic climate change effects will need to be addressed, as part of the EAFM by TRFMOs and other governance bodies (Maury et al., 2013). The provision of science to support TRFMOs decisions is critical (Hobday et al., 2013) and collaborative efforts are required between research disciplines and management agencies to better monitor and understand the impacts of short-term variability and longer-term climate change on oceanic fisheries (Salinger et al., 2013). Habitat models can be used to predict future impacts of anthropogenic climate change on tuna distribution and abundance (Hobday, 2010; Lehodey et al., 2013), allowing to develop alternative management strategies and adapt to future socio economic scenarios (Bell et al., 2013).

In spite of its pivotal role in future implementations of the EAFM within TRFMOs, current knowledge about tuna habitat preferences remains fragmented and heterogeneous. The latest generation of electronic tags have provided important new insights (Bestley et al., 2009; Galuardi and Lutcavage, 2012; Schaefer and Fuller, 2010; Schaefer et al., 2007). Although some large deployment efforts have characterised habitat preference and movement patterns at relevant scales for management (e.g. Block et al., 2005; Block et al., 2011; Hartog et al., 2011; Hazen et al., 2013; Hobday and Hartmann, 2006), most tagging studies are local with short deployment periods (e.g. Cosgrove et al., 2014), and provide information about habitat characteristics only around deployment areas (Hobday and Evans, 2013). 
Additional efforts to study tuna habitat preferences have been undertaken using fishery data, commonly assuming that CPUE is proportional to fish abundance. Data on the position and time of fishing events allow relationships between the presence and/or abundance of tunas with environmental conditions to inform habitat preferences using a range of modelling approaches. For example empirical distributions of relative abundance binned across environmental variables can inform habitat preferences (Cheung et al., 2013; Sagarminaga and Arrizabalaga, 2010; Zainuddin et al., 2006). Fromentin et al. (2014) characterised the environmental niche of Atlantic bluefin tuna using a non-parametric probabilistic environmental niche model (NPPEN, Beaugrand et al., 2011), and Reygondeau et al. (2012) used a hierarchical clustering method to identify different tuna and billfish communities and describe their environmental conditions. Several other authors used Generalized Linear Models (GLM, Briand et al., 2011, Lan et al., 2013) and Generalized Additive Models (GAMs, Lan et al., 2013; Maury et al., 2001; Mugo et al., 2010; Sagarminaga and Arrizabalaga, 2010) to describe habitat preferences of tunas. Finally, coupled biophysical models such as SEAPODYM (Lehodey et al., 2008) or APECOSM (Maury, 2010) are being used to describe the spatial dynamics of tunas and can incorporate different habitat indices (e.g. spawning habitat and feeding habitat) as well as submodels for the distribution of tuna forage (Bertignac et al., 1998, Lehodey et al., 1998). Guisan and Zimmermann (2000) suggest that there is no best model. Instead, the choice of the model depends on the objective of the study as well as the nature of the available data.

A range of environmental variables influence tuna spatial distribution. Temperature and oxygen affect important biological processes and thus determine the spatial distribution of tunas (Barkley et al., 1978; Boyce et al., 2008; Brill, 1994; Strama et al., 2012). Salinity can influence large scale spatial distribution (e.g. Fromentin et al., 2014; Maury et al., 2001; Reygondeau et al., 2012). The mixed layer depth can limit the vertical distribution of tuna and tuna like species (Bernal et al., 2009; Prince et al., 2010), while the sea surface height anomaly (SSH) provides information on the open-ocean physical habitat of pelagic species. For example, positive and negative anomalies are associated with eddies and gyres, describing convergent and divergent areas where tuna prey may aggregate. Frontal systems around these gyres can also potentially aggregate tunas (Arrizabalaga et al., 2008; Olson et al., 1994; Podestá et al., 1993; Royer et al., 2004; Sagarminaga and Arrizabalaga, 2014). In addition to the physical environment, the distribution of prey is also one of the main drivers of the spatial distribution and behaviour of tunas (Bertignac et al., 1998; Schick and Lutcavage, 2009, 
Bernal et al. 2009). Chen et al., 2005 have shown that higher primary production attracts tunas, but data on tuna prey distribution and abundance is scarce and is mostly available from models (Lehodey et al., 1998).

Habitat studies using fishery or survey data are often spatially limited and focused on single species (e.g. Chen et al., 2005; Sagarminaga and Arrizabalaga, 2010). Therefore, each study provides a particular view of the habitat preference of a given species or stock, commonly based on one variable (mostly sea surface temperature) or a limited set of environmental variables. In this context, comparison between different habitat preferences is difficult due to differences in the datasets, methods, and studied areas, and this affects our ability to determine which environmental variables are the most important drivers of tuna distribution. In fact, there are few studies where the habitat preferences of a group of species are analysed using similar datasets and methods at broad spatial scales (but see Reygondeau et al. 2012). Therefore, the aim of this study is, based on a common dataset and consistent methodology, to provide a global comparative perspective of habitat preferences for six commercially important tuna species and to identify the most important variables driving tuna spatial distribution.

\section{Material and methods}

\subsection{Fishery data}

The main commercial species of tuna, namely Atlantic bluefin, southern bluefin, albacore, bigeye, yellowfin and skipjack are considered. These large predators of the pelagic ecosystem are highly migratory and their distribution covers most of the tropical and temperate areas around the globe. They are mainly caught by industrial pelagic fisheries. Among the fishing methods, pelagic longlines show the largest spatio-temporal coverage, since they have operated for several decades across all oceans, targeting all main commercial tuna species except skipjack. Longlines resemble long baited transects and catch a wide range of species in a consistent way over a vast spatial scale and longline catch data have been previously used to analyse changes in abundance (Myers and Worm, 2003), diversity (Worm et al., 2005), range contraction (Worm and Tittensor, 2011) and biogeography (Reygondeau et al., 2012).

Tuna longline catch and effort data for the Atlantic, Indian and Pacific Oceans were obtained from the five TRFMOs, i.e. International Commission for the Conservation of Atlantic Tunas (ICCAT, www.iccat.int), Indian Ocean Tuna Commission (IOTC, www.iotc.org), Western 
and Central Pacific Fisheries Commission (WCPFC, www.wcpfc.int), Inter-American Tropical Tuna Commission (IATTC, www.iattc.org) and Commission for the Conservation of Southern Bluefin Tuna (CCSBT, www.ccsbt.org). Catch (tonnes, except for southern bluefin which is in number of fish) and effort (number of hooks) data were obtained for 1958 to 2007, the time span for which environmental data were available. Exceptions to this were data for southern bluefin tuna which were only available from 1965 and for eastern Pacific stocks which were only available until 2004. No data on skipjack caught by longline was available from the Western and Central Pacific. The spatio-temporal resolution was heterogeneous between sources of data, so all data were aggregated by quarter and $5^{\circ} \times 5^{\circ}$ spatial resolution. The degree of detail about the longline fleets involved was also heterogeneous. In this study we used data only from the Japanese fleet, except in the case of the WCPFC where fleet specific information was not available. Nominal CPUE was computed as the ratio of catch to the number of hooks for every observation, and the CPUE was assumed to be a proxy for fish abundance. Only positive CPUE records were considered.

\subsection{Environmental data}

The environmental data used were generated by the PISCES biogeochemical model (Pelagic Interaction Scheme for Carbon and Ecosystem Studies; Aumont and Bopp, 2006). PISCES has been extensively validated and has demonstrated the ability to realistically simulate seasonal, interannual and decadal physical and biogeochemical ocean variability. As such, it has been used at the global scale for a range of different purposes, including investigating the mechanisms that explain variability in marine productivity or the impact of ocean acidification on marine ecosystems (Aumont and Bopp, 2006; Bopp et al., 2005; Gorgues et al., 2005; Orr et al., 2005). PISCES includes a description of the planktonic community with four functional groups (Diatoms, Nano-phytoplankton, Micro-zooplankton and Mesozooplankton). For this study, and because tunas show a wide vertical distribution, we selected the following variables to characterise the surface and subsurface environment: surface temperature (TEMP5, in ${ }^{\circ} \mathrm{C}$ ) and temperature at 100m (TEMP100, in ${ }^{\circ} \mathrm{C}$ ), sea surface salinity (SAL, in PSU), dissolved oxygen at 100m (DO, in mol/l), sea surface height (SSH, in m), mixed layer depth (MLD, in m), chlorophyll (DCHL, in mol/l) and meso-zooplancton averaged over $0-100 \mathrm{~m}$ (ZOO, in $\mathrm{mol} / \mathrm{l})$. The latter two variables were used as a proxy for the biotic environment. All environmental variables were averaged to the same spatial $\left(5^{\circ} \times 5^{\circ}\right)$ and temporal (quarter) resolution as the fishery data. 


\subsection{Quotient analysis}

Tuna habitats were characterized in terms of geographical and environmental covariates extracted from the model using the quotient analysis technique (van der Lingen et al., 2001). In this method, the covariate of interest is divided into classes (equally sized bins) and the percentage of fishing locations and the percentage of total abundances per class are compared using the quotient:

$Q_{i}=\frac{A_{i} / \sum_{i} A_{i}}{N_{i} / \sum_{i} N_{i}}$

where $N_{i}$ and $A_{i}$ denote, respectively, number of locations and total abundance per class $i$. Quotients were calculated for each species and each environmental variable. Confidence intervals of the null hypothesis of even distribution (quotient equal to 1) were computed by a re-sampling procedure (following Bernal et al., 2007) with 400 iterations, in order to test for the significance of quotient values larger or smaller than 1 . Preference values were defined as values of the covariates in which the CPUE quotient is significantly larger than 1 (or greater than the upper confidence interval). Avoidance values are those values of the covariate for which the CPUE quotient is significantly lower than 1 (i.e., below the lower confidence interval). Tolerance range is defined as the range of neither significant avoidance nor significant preference.

\subsection{Generalized Additive Models}

Habitat models were built for each species using GAMs, which are non-parametric generalisations of multiple linear regression techniques (Hastie and Tibshirani, 1990). A GAM enables fitting non-linear models for a wide family of statistical distributions, and thus is preferred to some other habitat modelling approaches (Guisan and Zimmermann, 2000). GAMs have been previously used to study habitat preferences of many tuna species using fishery data (Lan et al., 2013; Maury et al., 2001; Mugo et al., 2010; Sagarminaga and Arrizabalaga 2010), larval survey data (Rooker et al., 2013) as well as electronic tagging data (Hazen et al., 2013). In this study, the use of GAMs allowed the quantification of the percentage of null deviance that can be explained by habitat, and to determine the relative contribution of the environmental variables. Positive CPUE observations were assumed to follow a lognormal error distribution and they were modelled as a function of the environmental variables, as well as fixed factors for “year”, “season” and "stock”. The 
environmental variables were modelled with spline functions. The degree of smoothness of model terms was restricted to 4 in order to assume a unimodal niche model (sensu Hutchinson, 1957). The fixed factors are intended to correct for spatial and temporal (seasonal and interannual) changes in abundance and/or catchability, although the estimated coefficients were not interpreted since the estimation of abundance and/or catchability trends is out of the scope of this paper. The "stock" factor, in addition to differences in abundance and/or catchability between oceans, also corrects for potential differences between TRFMOs in the way the data is gathered, that might affect average CPUE values.

For each species, two steps were undertaken: first, we built univariate GAMs, i.e. a GAM for each variable independently. Second, we built full GAMs with both environmental and fixed factors. Changes in abundance and catchability are likely to occur at the stock level and so three way interactions among fixed factors were considered in the full GAMs. Scatterplots between environmental variables suggested high collinearity $\left(\mathrm{R}^{2}>\mathrm{abs}(0.6)\right)$ between TEMP5 and TEMP100, TEMP5 and O2, and DCHL and ZOO (Figure 1). Thus, TEMP100, O2 and ZOO where excluded from the full GAMs. A stepwise backward model selection procedure was adopted, and the model with the lowest AIC was selected, following Chambers and Hastie (1992). Following the hierarchy principle, if an interaction was included in the model, lower order interactions and fixed factors were also included. The GAMs were built using the R v. 3.0 (R Development Core Team, 2013) and the mgcv 1.7-22 package (Wood, 2006). Missing values were omitted before the stepwise selection, so that model comparisons were based on the same dataset. The deviance explained by the model was estimated as 1-(residual deviance)/(null deviance), and is the equivalent to $\mathrm{R}^{2}$ in regression models (Guisan and Zimmermann, 2000). Selected models were used to predict and map the habitat preferences of all species. For predictions, the environmental variables were averaged across the whole period (1958-2007) in each position at a $1^{\circ} \times 1^{\circ}$ resolution, and fixed factors were set to reference levels.

\section{Results}

Global tuna CPUE is represented in Figure 2. Southern bluefin tuna CPUE shows the southernmost distribution, and was caught mainly between $30^{\circ} \mathrm{S}$ to $50^{\circ} \mathrm{S}$ in the Indian and Western Pacific Ocean. Atlantic bluefin tuna shows the northernmost distribution, up to around $60^{\circ} \mathrm{N}$, including the Mediterranean Sea. Albacore is a temperate to subtropical species with highest CPUEs between $20^{\circ}-40^{\circ}$ of each hemisphere. Relatively high CPUE for bigeye 
tuna is also observed between $40^{\circ} \mathrm{S}$ and $40^{\circ} \mathrm{N}$, while highest yellowfin CPUE are found around the equator. In the case of skipjack, whose northernmost distribution is limited to around $40^{\circ} \mathrm{N}$, highest CPUEs are observed around $20^{\circ}$ latitude in each hemisphere.

\subsection{Quotient analysis}

The quotient analysis revealed some expected, as well as some other more novel patterns of preference, tolerance and avoidance of tunas with respect to the environmental variables. For instance, it is well known that tropical tunas (skipjack, bigeye and yellowfin tuna) prefer warmer surface waters than temperate tunas (albacore, Atlantic bluefin and southern bluefin). However, the preference-tolerance-avoidance patterns with respect to some other environmental variables are seldom described in the literature. Among the tropical tunas, yellowfin prefers a higher (beyond $25^{\circ} \mathrm{C}$ ) surface temperature range than bigeye and skipjack (between $20^{\circ} \mathrm{C}$ and $28^{\circ} \mathrm{C}$ ). In the case of temperate tunas, the ranges of preference and tolerance are shifted to colder waters. Albacore avoids waters below $14^{\circ} \mathrm{C}$, which are preferred or tolerated by both Atlantic bluefin and southern bluefin. The preference range for southern bluefin and the tolerance range for Atlantic bluefin extend down to $4^{\circ} \mathrm{C}$ (Figure 3 , Figure S1). Similar patterns between species are observed for the subsurface temperature (TEMP100). It is remarkable that this analysis suggests that there is no well-established temperature preference, but the widest temperature tolerance range (approximately between $1^{\circ} \mathrm{C}$ and $20^{\circ} \mathrm{C}$ ) for Atlantic bluefin tuna.

Atlantic bluefin showed a marked preference and tolerance for high salinity waters (above 37 PSU), probably linked to the role of Mediterranean waters in their life cycle. Albacore and skipjack showed clearly defined preferred salinity ranges, at around 36-37 PSU. Bigeye, yellowfin and southern bluefin tuna showed less clearly defined preference windows that included lower salinity waters, as low as 33 PSU in the case of yellowfin.

In general, tropical tunas preferred lower oxygen environments than temperate tunas. Yellowfin tuna preferred a wide range of relatively low oxygen waters $(<0.2 \mathrm{mmol} / \mathrm{l})$ while bigeye tolerated them. Skipjack tolerance range was more restricted and avoided waters below $0.1 \mathrm{mmol} / \mathrm{l}$. All tropical tunas avoided oxygen rich environments that temperate tunas preferred/tolerated. Among the temperate tunas, albacore showed a relatively narrow preference-tolerance range compared to southern bluefin that showed the largest oxygen preference values. Atlantic bluefin tuna can also tolerate a similar range of oxygen values. 
Tropical tunas, as well as albacore, prefer slightly negative or positive values of SSH. Yellowfin and albacore can tolerate higher SSH than bigeye and skipjack. On the contrary, bluefin tunas showed preference and tolerance for negative SSH values, Atlantic bluefin preferring most negative values.

Relatively stratified waters (mixed layer depth $<80 \mathrm{~m}$ ) are preferred by tropical tunas compared to temperate tunas. Albacore preference and tolerance ranges extend to about 200 $\mathrm{m}$, while southern bluefin tuna preference range extends to highly mixed waters with mixed layer depths of several hundred meters that Atlantic bluefin tuna tolerates.

In general, relatively low DCHL and ZOO waters are preferred by tropical tunas and albacore, compared to both bluefin tunas, for which the preference and tolerance ranges are not very well defined, but results suggest that they can tolerate a wide range of DCHL and ZOO values.

\subsection{Generalized additive models}

In the univariate GAMs, the "stock” factor explained a relatively high proportion of the null deviance in the case of skipjack (23\%), bigeye (20\%) and albacore (12\%), but less than $1 \%$ for other species (Table 1). The percent deviance explained by the "year” factor varied between $2 \%$ (in the case of bigeye) and 21\% (in the case of skipjack), while that explained by the "season" factor was minor ( $<2 \%$ in all cases except for bluefin). TEMP5 was the most important variable for yellowfin tuna, as TEMP100 was for southern bluefin. The proportion of null deviance explained by these two temperature related variables ranged between $38 \%$ (for southern bluefin) and 2\% (skipjack) of total deviance. Oxygen, highly correlated with temperature, explained similar proportions. Salinity explained between $17 \%$ and $4 \%$ of the null deviance for southern bluefin, skipjack, albacore and Atlantic bluefin, with less than 2\% for yellowfin and bigeye.

SSH was the environmental variable that explained the highest percentage of deviance (22\%) in the case of Atlantic bluefin, and between $28 \%$ and 5\% for the rest of the species, except for albacore $(<1 \%)$. In the case of MLD, the percentage explained was moderate, ranging between $10 \%$ (in the case of yellowfin) and $2 \%$ (in the case of skipjack). The percentage of 
null deviance explained by DCHL and ZOO was also generally moderate, between $8 \%$ and $1 \%$.

The full GAMs explained between 45\% (for bigeye) and 64\% (for skipjack) of the null deviance (table 2). For all species, the full GAMs selected with the AIC criteria included all the 5 environmental variables TEMP5, SAL, SSH, MLD and DCHL. They also generally included the three way stock:year:season interaction for fixed factors, except in the case of albacore where the interactions stock:year and stock:season were kept in the final model, and in the case of southern bluefin, with a single stock, where the year:season interaction was included.

In general, model predicted distributional ranges and relative densities matched well the observations (Figure 2). However, some unexpected patterns were observed out of the range of observed values. The predictions for the species with most extensive data coverage (albacore, yellowfin, bigeye) were reasonable, with poor habitat predictions out of the observed range (e.g. north of $50^{\circ} \mathrm{N}$ and south of $50^{\circ} \mathrm{S}$ ). In the case of southern bluefin, the models predicted suitable habitat also in the northern fringe $\left(>40^{\circ} \mathrm{N}\right)$ of the planet (where there are no observations of southern bluefin), but middle latitudes would act as a barrier to potential expansion from south to north. In the case of Atlantic bluefin, the model identifies the Mediterranean and the northern Atlantic $\left(>40^{\circ} \mathrm{N}\right)$ as most suitable, habitat suitability increasing further north beyond the northern range of the observations and decreasing towards the equator and southern hemisphere in spite of important catches that occurred in the past (Fromentin et al., 2014). In the case of skipjack (for which data were not available over the whole globe and is a bycatch species in longline fisheries), suitable habitat was predicted in areas with no observations, e.g. the Mediterranean, and at extreme latitudes around $60^{\circ} \mathrm{S}$ in the southern ocean and at around $60^{\circ} \mathrm{N}$ in the north Atlantic. The environmental variables in these areas are out of the ranges used in the skipjack model and thus the GAM predictions are unrealistic. However, skipjack model predictions within the observational range were reasonable.

The final GAMs were kept as those describing the habitat of the tuna species, and their response curves for environmental variables were interpreted in terms of habitat suitability (Figure 4). The fitted smooth curves show the preference for warm waters (between $20^{\circ} \mathrm{C}$ and $30^{\circ} \mathrm{C}$ ) in the case of tropical tunas, for temperate waters (around $15^{\circ} \mathrm{C}$ ) in the case of albacore 
and Atlantic bluefin tuna, and for colder waters $\left(<10^{\circ} \mathrm{C}\right)$ in the case of southern bluefin.

Salinity response curves showed a peak slightly above 35 PSU for southern bluefin, remained high above 36 PSU for Atlantic bluefin and showed an increasing trend beyond 36 PSU for albacore. Bigeye and yellowfin showed decreasing trends beyond 34 and 35 PSU respectively, but increasing trends were seen for skipjack. Response curves for SSH suggested that positive SSH anomalies were preferred by southern bluefin, albacore and skipjack, and negative SSH anomalies were preferred by Atlantic bluefin, bigeye, yellowfin and also by skipjack. Southern bluefin tuna preferred mixed layer depths beyond approximately $300 \mathrm{~m}$, while Atlantic bluefin showed a clear preference for increasing mixed layer depths. Preferred mixed layer depths were between 50 and 400m for albacore, bigeye and yellowfin tunas. Albacore preferred low DCHL waters, while southern bluefin, Atlantic bluefin and yellowfin showed an optimum at relatively high concentrations. In spite of being selected in the final model, some response curves were relatively flat during most of the observed range (e.g. DCHL for bigeye and skipjack, or MLD for yellowfin and skipjack), suggesting a relatively low influence of these environmental variables compared to the others.

\section{Discussion}

Our study described tuna habitat and distribution as characterised by a set of environmental variables. Some of these variables (e.g. temperature, DCHL) have been used in previous studies (e.g. Sagarminaga and Arrizabalaga 2010; Mugo et al., 2010), but description of the habitat preferences based on other variables (e.g. MLD, ZOO) is rarely found in the literature. When available, these studies are limited to a single species and/or small areas (e.g. Dell et al., 2011). In our study, we use a common dataset and consistent approaches (quotient analysis and GAMs) to provide a comprehensive view of habitat preferences of six tuna species with respect to eight environmental variables that can be utilized in future studies and contribute to integrate the EAFM in the TRFMOs (e.g. through spatial approaches to management, or to anticipate climate change effects on populations and fisheries).

Fishery data have been criticised for inducing biased conclusions about stock abundance trends because CPUE series may not accurately reflect trends of population abundance due to changes in fishing practice, efficiency of the fleets or environmental effects on catchability, among others (see Maunder and Punt, 2004; Maunder et al., 2006; Polacheck, 2006). In our case, we included fixed factors in the GAMs to accommodate changes in abundance and catchability. Moreover, interpreting abundance trends was out of the scope of this paper, 
which focussed on revealing habitat preferences. In fact, extensive longline datasets with broad spatio-temporal coverage have supported a number of studies in relation to tuna distribution and habitat preferences (e.g. Fromentin et al., 2014; Reygondeau et al., 2012; Worm and Tittensor, 2011).

Reygondeau et al. (2012) proposed a conceptual scheme where yellowfin, bigeye, albacore and bluefin species dominated different ecoregions as latitude increased. Our habitat predictions are generally consistent with that view, although latitudinal ranges of suitable habitat for bigeye tuna were comparable to those of albacore. Our predicted distributional ranges for albacore, bigeye and yellowfin were also comparable to those in Worm and Tittensor (2011), but were more extensive for both bluefin species and skipjack. This could be due to using a longer timeframe (including observations from the 1950s and the 2000s) as well as differences in data filtering prior to analysis. In the case of southern bluefin tuna, the predicted distribution in Eastern Australia was consistent with Hobday and Hartmann (2006) and Hartog et al. (2011). However, our habitat predictions showed a slightly higher latitudinal range compared to those predicted by coupled biophysical models in the case of skipjack in the Pacific Ocean (Bell et al., 2013; Lehodey et al., 2013), Indian Ocean (Dueri, 2012), and worldwide (Dueri, 2014), as well as in the case of Pacific bigeye tuna (Lehodey et al., 2010). The observed differences may be because our prediction represents a multidecadal average while those other studies show predictions for a more limited timeframe, or because they integrate additional data from purse seine and baitboat fisheries operating in tropical areas. However, another important difference is that biophysical models integrate, in addition to data on the physical habitat, biological dynamics (e.g. movement) that can concentrate the distribution of the population with respect to that of the suitable habitat (Dueri et al 2014).

Although GAMs are statistically more rigorous than quotient analyses, similar environmental preferences were estimated with both approaches, especially for the variables showing most contrasting response curves in the final GAMs (TEMP5, SAL and SSH). However, due to collinearity issues, not all environmental variables were included in the GAMs. For instance, although temperature was an important variable for all species, other correlated variables like oxygen, not included in the GAMs, could similarly explain the observations. The quotient analysis (as well as the univariate GAMs) allows the description of the preferences with respect to each environmental variable, which could be useful when preferences for a variable not included in the final GAMs are required. This could be the case for oxygen, since the 
spatial distribution of oxygen levels has been suggested to influence large pelagic species distribution and catchability (Prince et al., 2010).

GAMs provide a continuous response curve of habitat suitability, while the quotient analysis allowed discriminating between preference, tolerance and avoidance ranges for a particular variable. Our definitions of tuna habitat preferences do not necessarily coincide with those used by other authors using other methods, thus comparison of our findings with previous studies may not be straightforward. For instance, the Cheung et al. (2013) definition of the temperature preference is similar to the quotient formula used here. However, they do not classify preference, tolerance and avoidance ranges following a statistical procedure as done in our study. Instead, they calculate the preference profile and provide the most preferred range of temperatures for each species characterized by the $25^{\text {th }}, 50^{\text {th }}$ and $75 \%$ percentiles. Boyce et al. (2008) define tolerance as the whole range of observed temperatures, and preference as the range where the species spent most ( $>40 \%)$ of the time during the studies they analyzed.

There have been several studies using alternative techniques, datasets and models, providing comprehensive descriptions of the habitat preferences of tunas in the past (see Boyce et al., 2008; Brill, 1994; Brill and Lutcavage, 2001; Sund et al., 1981). Most detailed studies, using tagging data (e.g. Galuardi et al., 2010; Schaefer et al., 2014), fine scale fishery datasets (e.g. Briand et al., 2011; Sagarminaga and Arrizabalaga, 2010) and fine scale environmental observations from surveys or satellites (e.g. Druon et al., 2011; Royer et al., 2004) focused on relatively small spatial scales (e.g. the range of the local fishery activity or the spatial range visited by the tagged tunas during a relatively short period of time), hampering comparative analyses.

Considering the differences in the nature of the data and the approach used, our results are generally consistent with several other studies. For example, temperature preferences provided in Boyce et al. (2008) are comparable to those provided in this study. However, Hazen et al. (2013), using an extensive and detailed tagging dataset, estimated an optimum of around $20^{\circ} \mathrm{C}$ for yellowfin, while our results of both the quotient analysis and the GAM suggest a preference for waters of up to $30^{\circ} \mathrm{C}$. This discrepancy might be due to the different areas analysed, since their study focussed on the north-eastern Pacific, while ours included the entire tropical region. In the case of albacore, our quotient analysis results for temperature 
preference (up to and beyond $20^{\circ} \mathrm{C}$ ) are comparable to those of Hazen et al. (2013), while our GAM results suggest somewhat lower preferred values (around $15^{\circ} \mathrm{C}$ ), more in line with Boyce et al. (2008) and Lan et al. (2012). The higher chlorophyll preferences in Hazen et al. (2013) are also explained because their study area, containing important upwelling systems, is on average richer in chlorophyll. The 25\%-75\% interquartile range of the temperature preference profile in Cheung et al. (2013) is also consistent with our estimates, but in the case of temperate tunas the tolerance we estimated extended to colder waters. This could have several explanations. First, both studies have a different definition of tolerance. Moreover, Cheung et al. (2013) focussed on Large Marine Ecosystems which encompass relatively coastal waters compared to more oceanic areas in our study. Some tunas can visit coastal areas in summer to feed (e.g. see Goñi and Arrizabalaga, 2010), but they overwinter in oceanic waters. Since our study is focussed on oceanic waters, this might explain the differences observed with respect to Cheung et al. (2013). Finally, our study reflects mostly habitat preferences for adult tunas (since it is based on longline data that mostly catches adult fish), and this could also explain some of the discrepancies with respect to other studies.

The quotient analysis showed the widest tolerance ranges (i.e. for TEMP5, TEMP100, SAL, SSH, MLD, and ZOO) for Atlantic bluefin tuna. In fact, it is the only species where TEMP5 is relatively non important. This finding is in agreement with other studies (Boyce et al., 2008; Cheung et al., 2013; Fromentin et al., 2014; Hazen et al., 2013; Lutcavage et al., 2000; Teo et al., 2007; Walli et al., 2009), and suggests that bluefin tuna is the species able to tolerate the widest ranges of environmental conditions, as supported by its physiological capabilities (Block et al., 2001; Block and Stevens, 2001). Fromentin et al. (2014) stated that the abiotic niche for Atlantic bluefin tuna is unusually large for a bony fish and our findings tend to confirm that Atlantic bluefin can also tolerate a wide range of biotic environments (in terms of plankton concentrations). To a lesser degree, southern bluefin tuna also showed wide tolerance ranges to environmental conditions, probably due to the diversity of habitats encountered in the southern ocean and the plastic behaviours in response to their changing ocean environment (Bestley et al., 2009).

Determining the relative importance of environmental variables is challenging. For instance, temperature and oxygen are considered to be important variables determining tuna habitat (Brill, 1994; Li et al., 2012). They both explained a relatively high percentage of deviance in univariate GAMs, but the correlation between them impeded inclusion of oxygen in the final 
GAMs, thus not allowing a determination of relative importance. Response curves for SAL, TEMP5 and SSH generally showed more contrast in comparison to those of MLD and DCHL. This, together with the univariate GAM results, suggests that these three variables are among the most important drivers of tuna spatial distribution. Results with respect to SSH were consistent with other finer scale studies suggesting Atlantic bluefin preference for negative SSH characteristic of mesoscale cyclonic eddies (Teo and Block, 2010) and skipjack preference for zero to positive anomalies (Mugo et al., 2010). In the case of yellowfin, MLD appeared slightly more important than SSH. This is in agreement with Dell et al. (2011) who, using a detailed fishery database, found MLD to be more important than SSH for yellowfin in the Tasman Sea. However, they also identified DCHL as one of the important variables for yellowfin. The importance of DCHL was also suggested by Briand et al. (2011), using a detailed fishery dataset, for Pacific albacore. These results regarding the importance of DCHL are consistent with our results, since response curves for this variable showed relatively higher influences in these two species compared to bigeye or skipjack where the response curves were rather flat. Still, spatio-temporally averaged DCHL values might not best determine, by themselves, the distribution of these visual predators, compared with DCHL fronts to which tunas might be attracted (Brill and Lutcavage, 2001; Royer et al., 2004; Sagarminaga and Arrizabalaga, 2014). Moreover, the effects of such fronts on tuna distribution might not be detectable with the spatio-temporal resolution used in this study.

The importance of salinity for tuna distribution remains controversial in the literature, with some suggesting it is not important in influencing oceanic distribution (Sund et al., 1981), while others have found it to be influential (e.g. Bernal et al., 2009; Maury et al., 2001; Reygondeau et al., 2012). Our GAM results tend to support the importance of salinity since this variable showed variable response curves for all the species. However, the mechanisms through which salinity could affect tuna distribution remain unclear and could be a proxy of other underlying processes. Maury et al. (2001) suggested that low salinities could indicate favourable trophic areas induced by fluvial water supplies. In fact, trophic resources must play a major role in the spatial distribution of tunas, as suggested by several relatively small scale studies (Bestley et al., 2009; Lezama et al., 2010; Schick and Lutcavage, 2009) and the fact that tunas conduct, as part of their life cycles, extensive trophic migrations to exploit seasonally productive areas (e.g. Dufour et al. 2010, Fonteneau et al., 2008). In this study, we have used DCHL and ZOO as simple proxies for prey concentration, but trophodynamics of tunas are complex and dynamic (Young et al., 2014). The general lack of prey field 
observations at both small and larger spatial scales prevents the study of their impact on tuna distribution. Future model developments (e.g. Lehodey et al., 2008) as well as new acoustic technologies (e.g. Handegard et al., 2013) may be able to provide further insights on the relative importance of biotic and abiotic variables.

Additional insights into tuna habitat preferences are expected to arise from electronic tagging experiments. So far, in most of the tagging studies, the spatial and temporal extent of data time series is often limited in relation to the total distribution of the populations, and the temporal and spatial scale of environmental influences may not be well captured. Tagging data are often biased to those areas closest to deployments because of short temporal periods at liberty and an associated lack of dispersal across the full extent of the species range (Hobday and Evans, 2013). In the future, additional development of electronic tags (e.g. including new sensors), as well as new approaches to the analysis of the data they generate (e.g. by identifying spawning (Aranda et al., 2013) and feeding (Bestley et al., 2008) activity), will be helpful to characterize spawning and feeding habitats of tunas. Achieving longer deployments and lowered prices to allow sustained and widespread use (e.g. Block et al., 2011; Hazen et al., 2013) would also be desirable. Although some initiatives are underway (Musyl et al., 2011), further development of tagging data sharing protocols and tools would allow global habitat analyses based on detailed datasets. In the meantime, fishery data remain a valuable source of information to analyse global habitat of tunas at broad spatial and temporal scales.

Acknowledgements: This research was funded by the EU Marie Curie EST project METAOCEANS (MEST-CT-2005-019678) and by the European Commission (Contract No. 264933, EURO-BASIN: European Union Basin-scale Analysis, Synthesis and Integration). This paper is contribution number XXX from AZTI-Tecnalia (Marine Research). We thank all TRFMOs for the datasets and help, as well as Alistair Hobday and two anonymous reviewers for their suggestions. This research was conducted as part of the CLIOTOP program. 


\section{References}

Albaina, A., Iriondo, M., Velado, I., Laconcha, U., Zarraonaindia, I., Arrizabalaga, H., Pardo, M.A., Lutcavage, M., Grant, W.S., Estonba, A., 2013. Single nucleotide polymorphism discovery in albacore and Atlantic bluefin tuna provides insights into worldwide population structure. Animal Genet. 44, 678-692.

Aranda, G., Abascal, F.J., Varela, J.L., Medina, A., 2013. Spawning Behaviour and PostSpawning Migration Patterns of Atlantic Bluefin Tuna (Thunnus thynnus) Ascertained from Satellite Archival Tags. PLoS ONE 8(10): e76445. doi:10.1371/journal.pone.0076445

Arrizabalaga, H., Pereira, J.G., Royer, F., Galuardi, B., Goñi, N., Artetxe, I., Arregi, I., Lutcavage, M., 2008. Bigeye tuna (Thunnus obesus) vertical movements in the Azores Islands determined with pop-up satellite archival tags. Fish. Oceanogr. 17, 74-83.

Aumont, O., Bopp, L., 2006. Globalizing results from ocean in situ iron fertilization studies. Glob. Biogeochem. Cycles 20, GB2017.

Barkley, R.A., Neill, W.H., Gooding, R.M., 1978. Skipjack tuna, Katsuwomuns pelamis, habitat based on temperature and oxygen requirements. Fish. Bull. 76, 653-662.

Beaugrand, G., Lenoir, S., Ibañez, F., Manté, C., 2011. A new model to assess the probability of occurrence of a species, based on presence-only data. Mar. Ecol. Prog. Ser. 424, 175-190.

Bell, J.D., Ganachaud, A., Gehrke, P.C., Griffiths, S.P., Hobday, A.J., Hoegh-Guldberg, O., Johnson, J.E., Le Borgne, R., Lehodey, P., Lough, J.M., Matear, R.J., Pickering, T.D., Pratchett, M.S., Gupta, A.S., Senina, I., Waycott, M., 2013. Mixed responses of tropical Pacific fisheries and aquaculture to climate change. Nat. Clim. Change 3, 591599.

Bernal, M., Stratoudakis, Y., Coombs, S., Angelico, M.M., Lago de Lanzós, A., Porteiro, C., Sagarminaga, Y., Santos, M., Uriarte, Á., Cunha, E., Valdés, L., Borchers, D., 2007. Sardine spawning off the European Atlantic coast: Characterization of and spatiotemporal variability in spawning habitat. Prog. in Oceanogr. 74, 210-227.

Bernal, D., Sepulveda, C., Musyl, M.K., Brill, R.W., 2009. The Eco-physiology of swimming and movement patterns of tunas, billfishes, and larger pelagic sharks, in: Domenici, P., Kapoor, B.G. (Eds.), Fish Locomotion; An Etho-ecological Approach. Science Publishers, Enfield, NH, pp. 436-483.

Bertignac, M., Lehodey, P., Hampton, J. 1998. A spatial population dynamics simulation 
model of tropical tunas using a habitat index based on environmental parameters. Fish. Oceanogr. 7, 326-334.

Bestley, S., Patterson, T.A., Hindell, M.A., Gunn, J.S., 2008. Feeding ecology of wild migratory tunas revealed by archival tag records of visceral warming. J. of Anim. Ecol. 77, 1223-1233.

Bestley, S., Gunn, J.S., Hindell, M.A., 2009. Plasticity in vertical behaviour of migrating juvenile southern bluefin tuna (Thunnus maccoyii) in relation to oceanography of the south Indian Ocean. Fish. Oceanogr. 18, 237-254.

Block, B.A., Stevens, E., 2001. Tuna: Physiology, Ecology and Evolution, Fish physiology. Vol. 19, Academic Press, San Diego, California.

Block, B.A., Dewar, H., Blackwell, S.B., Williams, T.D., Prince, E.D., Farwell, C.J., Boustany, A., Teo, S.L.H., Seitz, A., Walli, A., Fudge, D., 2001. Migratory Movements, Depth Preferences, and Thermal Biology of Atlantic Bluefin Tuna. Sci. 293, 1310-1314.

Block, B.A., Teo, S.L.H., Walli, A., Boustany, A., Stokesbury, M.J.W., Farwell, C.J., Weng, K.C., Dewar, H., Williams, T.D., 2005. Electronic tagging and population structure of Atlantic bluefin tuna. Nat. 434, 1121-1127.

Block, B.A., Jonsen, I.D., Jorgensen, S.J., Winship, A.J., Shaffer, S.A., Bograd, S.J., Hazen, E.L., Foley, D.G., Breed, G.A., Harrison, A.-L., Ganong, J.E., Swithenbank, A., Castleton, M., Dewar, H., Mate, B.R., Shillinger, G.L., Schaefer, K.M., Benson, S.R., Weise, M.J., Henry, R.W., Costa, D.P., 2011. Tracking apex marine predator movements in a dynamic ocean. Nat. 475, 86-90.

Bopp, L., Aumont, O., Cadule, P., Alvain, S., Gehlen, M., 2005. Response of diatoms distribution to global warming and potential implications: A global model study. Geophys. Res. Lett. 32, L19606.

Boyce, D.G., Tittensor, D.P., Worm, B., 2008. Effects of temperature on global patterns of tuna and billfish richness. Mar. Ecol. Prog. Ser. 355, 267-276.

Briand, K., Molony, B., Lehodey, P., 2011. A study on the variability of albacore (Thunnus alalunga) longline catch rates in the southwest Pacific Ocean. Fish. Oceanogr. 20, 517-529.

Brill, R.W., 1994. A review of temperature and oxygen tolerance studies of tunas pertinent to fisheries oceanography, movement models and stock assessments. Fish. Oceanogr. 3, 204-216.

Brill, R.W., Lutcavage, M.E., 2001. Understanding environmental influences on movements 
and depth distributions of tunas and billfishes can significantly improve population assessments. Am. Fish. Soc. Symp. 25, 179-198.

Chambers, J.M., Hastie, T.J., 1992. Statistical Models in S. Chapman \& Hall, London.

Chen, I.-C., Lee, P.-F., Tzeng, W.-N., 2005. Distribution of albacore (Thunnus alalunga) in the Indian Ocean and its relation to environmental factors. Fish. Oceanogr. 14, 71-80.

Cheung, W.W.L., Watson, R., Pauly, D., 2013. Signature of ocean warming in global fisheries catch. Nat. 497, 365-369.

Cosgrove, R., Arregui, I., Arrizabalaga, H., Goni, N., Sheridan, M., 2014. New insights to behaviour of North Atlantic albacore tuna (Thunnus alalunga) observed with pop-up satellite archival tags. Fish. Res. 150, 89-99.

Dell, J., Wilcox, C., Hobday, A.J., 2011. Estimation of yellowfin tuna (Thunnus albacares) habitat in waters adjacent to Australia's East Coast: making the most of commercial catch data. Fish. Oceanogr. 20, 383-396.

Druon, J.N., Fromentin, J.M., Aulanier, F., Heikkonen, J., 2011. Potential feeding and spawning habitats of Atlantic bluefin tuna in the Mediterranean Sea. Mar. Ecol. Prog. Ser. 439, 223-240.

Dueri, S., Faugeras, B., Maury, O., 2012. Modelling the skipjack tuna dynamics in the Indian Ocean with APECOSM-E: Part 1. Model formulation. Ecol. Model. 245, 41-54.

Dueri, S., Bopp, L., Maury, O., 2014. Projecting the impacts of climate change on skipjack tuna abundance and spatial distribution. Glob. Chang. Biol. doi: 10.1111/gcb.12460.

Dufour, F., Arrizabalaga, H., Irigoien, X., Santiago, J., 2010. Climate impacts on albacore and bluefin tunas migrations phenology and spatial distribution. Prog. in Oceanogr. 86, 283-290.

FAO, 2011. Tuna and tuna-like species, in: Review of the state of world marine fishery resources. FAO Fisheries and Aquaculture Technical Paper No. 569. Rome, pp. 227-243.

Fonteneau, A., Lucas, V., Tewkai, A., Delgado, A. and Demarcq, H., 2008. Mesoscale exploitation of a major tuna concentration in the Indian Ocean. Aquat. Living Resour. $21,109-121$.

Fromentin, J.M., Reygondeau, G., Bonhommeau, S., Beaugrand, G., 2014. Oceanographic changes and exploitation drive the spatio-temporal dynamics of Atlantic bluefin tuna (Thunnus thynnus). Fish. Oceanogr. 23, 147-156.

Galuardi, B., Royer, F., Gloet, W., Logan, J., Neilson, J., Lutcavage, M., 2010. Complex migration routes of Atlantic bluefin tuna (Thunnus thynnus) question current 
population structure paradigm. Can. J. Fish. Aquat. Sci. 67, 966-976.

Galuardi, B., Lutcavage, M., 2012. Dispersal routes and habitat utilization of juvenile Atlantic bluefin tuna, Thunnus thynnus, tracked with mini PSAT and archival tags. Plos ONE 7, e37829.

Goñi, N., Arrizabalaga, H., 2010. Seasonal and interannual variability of fat content of juvenile albacore (Thunnus alalunga) and bluefin (Thunnus thynnus) tunas during their feeding migration to the Bay of Biscay. Prog. in Oceanogr. 86, 115-123.

Gorgues, T., Menkes, C., Aumont, O., Vialard, J., Dandonneau, Y., Bopp, L., 2005.

Biogeochemical impact of tropical instability waves in the equatorial Pacific. Geophys. Res. Lett. 32, L24615.

Guisan, A., Zimmermann, N.E., 2000. Predictive habitat distribution models in ecology. Ecol. Model. 135, 147-186.

Handegard, N.O., Buisson, L.d., Brehmer, P., Chalmers, S.J., De Robertis, A., Huse, G., Kloser, R., Macaulay, G., Maury, O., Ressler, P.H., Stenseth, N.C., Godø, O.R., 2013. Towards an acoustic-based coupled observation and modelling system for monitoring and predicting ecosystem dynamics of the open ocean. Fish and fish. 14, 605-615.

Hartog, J.R., Hobday, A.J., Matear, R., Feng, M., 2011. Habitat overlap between southern bluefin tuna and yellowfin tuna in the east coast longline fishery - implications for present and future spatial management. Deep Sea Res. Part II 58, 746-752.

Hastie, T., Tibshirani, R., 1990. Generalized additive models. Chapman and Hall, London.

Hazen, E.L., Jorgensen, S., Rykaczewski, R.R., Bograd, S.J., Foley, D.G., Jonsen, I.D., Shaffer, S.A., Dunne, J.P., Costa, D.P., Crowder, L.B., Block, B.A., 2013. Predicted habitat shifts of Pacific top predators in a changing climate. Nat. Clim. Chang. 3, 234238.

Hobday, A.J., Hartmann, K., 2006. Near real-time spatial management based on habitat predictions for a longline bycatch species. Fish. Manag. and Ecol. 13, 365-380.

Hobday, A.J., 2010. Ensemble analysis of the future distribution of large pelagic fishes off Australia. Prog. in Oceanogr. 86, 291-301.

Hobday, A.J., Hartog, J.R., Spillman, C.M., Alves, O., 2011. Seasonal forecasting of tuna habitat for dynamic spatial management Can. J. Fish. Aquat. Sci. 68, 898-911.

Hobday, A.J., Evans, K., 2013. Detecting climate impacts with oceanic fish and fisheries data. Clim. Chang. 119, 49-62.

Hobday, A.J., Young, J.W., Abe, O. Costa, D.P., Cowen, R.K., Evans, K., Gasalla, M.A., Kloser, R., Maury, O., Weng, K.C., 2013. Climate impact and oceanic top predators: 
moving from impacts to adaptation in oceanic systems. Rev. Fish Biol. Fish. DOI 10.1007/s11160-013-9311-0.

Hutchinson, G.E., 1957. Concluding Remarks. Cold Spring Harbor Symposia on Quantitative Biology 22, 415-427.

Kaplan, D.M., Bach, P., Bonhommeau, S., Chassot, E., Chavance, P., Dagorn, L., Davies, T., Dueri, S., Fletcher, R., Fonteneau, A., Fromentin, J.M., Gaertner, D., Hampton, J., Hilborn, R., Hobday, A., Kearney, R., Kleiber, P., Lehodey, P., Marsac, F., Maury, O., Mees, C., Ménard, F., Pearce, J., Sibert, J., 2013. The True Challenge of Giant Marine Reserves. Sci. 340, 810-811.

Lan, K.W., Kawamura, H., Lee, M.-A., Lu, H.-J., Shimada, T., Hosoda, K., Sakaida, F., 2012. Relationship between albacore (Thunnus alalunga) fishing grounds in the Indian Ocean and the thermal environment revealed by cloud-free microwave sea surface temperature. Fish. Res. 113, 1-7.

Lan, K.W., Evans, K., Lee, M.A., 2013. Effects of climate variability on the distribution and fishing conditions of yellowfin tuna (Thunnus albacares) in the western Indian Ocean. Climat. Chang. 119, 63-77.

Lehodey, P., Bertignac, M., Hampton, J., Lewis, A., Picaut, J., 1997. El niño Southern Oscillation and tuna in the western Pacific. Nat. 389, 715-718.

Lehodey, P., Andre, J.M., Bertignac, M., Hampton, J., Stoens, A., Menkes, C., Memery, L., Grima, N., 1998. Predicting skipjack tuna forage distributions in the equatorial Pacific using a coupled dynamical bio-geochemical model. Fish. Oceanogr. 7, 317-325.

Lehodey, P., Senina, I., Murtugudde, R., 2008. A spatial ecosystem and populations dynamics model (SEAPODYM) - Modeling of tuna and tuna-like populations. Prog. in Oceanogr. 78, 304-318.

Lehodey, P., Senina, I., Sibert, J., Bopp, L., Calmettes, B., Hampton, J., Murtugudde, R., 2010. Preliminary forecasts of Pacific bigeye tuna population trends under the A2 IPCC scenario. Prog. In Oceanogr. 86, 302-315.

Lehodey, P., Senina, I., Calmettes, B., Hampton, J., Nicol, S., 2013. Modelling the impact of climate change on Pacific skipjack tuna population and fisheries. Clim. Chang. 119, 95-109.

Lezama-Ochoa, A., Boyra, G., Goñi, N., Arrizabalaga, H., Bertrand, A., 2010. Investigating relationships between albacore tuna (Thunnus alalunga) CPUE and prey distribution in the Bay of Biscay. Prog. in Oceanogr. 86, 105-114.

Li, Y., Song, L., Nishida, T., Gao, P., 2012. Development of integrated habitat indices for 
bigeye tuna, Thunnus obesus, in waters near Palau. Mar. and Freshw. Res. 63, 12441254.

Lutcavage, M.E., Brill, R.W., Skomal, G.B., Chase, B.C., Goldstein, J.L., Tutein, J., 2000. Tracking adult North Atlantic bluefin tuna (Thunnus thynnus) in the northwestern Atlantic using ultrasonic telemetry. Mar. biol. 137, 347-358.

Maunder, M.N., Punt, A.E., 2004. Standardizing catch and effort data: a review of recent approaches. Fish. Res. 70, 141-159.

Maunder, M.N., Sibert, J.R., Fonteneau, A., Hampton, J., Kleiber, P., Harley, S.J., 2006. Interpreting catch per unit effort data to assess the status of individual stocks and communities. ICES J. of Mar. Sci. 63, 1373-1385.

Maury, O., Gascuel, D., Marsac, F., Fonteneau, A., De Rosa, A.-L., 2001. Hierarchical interpretation of nonlinear relationships linking yellowfin tuna (Thunnus albacares) distribution to the environment in the Atlantic Ocean. Can. J. Fish Aquat. Sci. 58, 458469.

Maury, O., 2010. An overview of APESCOM, a spatialized mass balanced “Apex Predators ECOSystem Model” to study physiologically structured tuna population dynamics in their ecosystem. Progr. Oceanogr. 84: 113-117.

Maury, O., Miller, K., Campling, L., Arrizabalaga, H., Aumont, O., Bodin, Ö., Guillotreau, P., Hobday, A.J., Marsac, F., Suzuki, Z., Murtugudde, R., 2013. A global sciencepolicy partnership for progress toward sustainability of oceanic ecosystems and fisheries. Curr. Opin. in Environ. Sustain. 5, 314-319.

Mugo, R., Saitoh, S.-i., Nihira, A., Kuroyama, T., 2010. Habitat characteristics of skipjack tuna (Katsuwonus pelamis) in the western North Pacific: a remote sensing perspective. Fish. Oceanogr. 19, 382-396.

Musyl, M.K., Domeier, M.L., Nasby-Lucas, N., Brill, R.W., McNaughton, L.M., Swimmer, J.Y., Lutcavage, M.S., Wilson, S.G., Galuardi, B., Liddle, J.B., 2011. Performance of pop-up satellite archival tags. Mar. Ecol. Prog. Ser. 433, 1-28.

Myers, R.A., Worm, B., 2003. Rapid worlwide depletion of predatory fish communities. Nat. 423, 280-283.

Olson, D.B., Hitchcock, G.L., Mariano, A.J., Ashjian, C.J., Peng, G., Nero, R.W., Podestá, G.P., 1994. Life on the edge: marine life and fronts. Oceanogr. 7, 52-60.

Orr, J.C., Fabry, V.J., Aumont, O., Bopp, L., Doney, S.C., Feely, R.A., Gnanadesikan, A., Gruber, N., Ishida, A., Joos, F., Key, R.M., Lindsay, K., Maier-Reimer, E., Matear, R., Monfray, P., Mouchet, A., Najjar, R.G., Plattner, G.-K., Rodgers, K.B., Sabine, C.L., 
Sarmiento, J.L., Schlitzer, R., Slater, R.D., Totterdell, I.J., Weirig, M.-F., Yamanaka, Y., Yool, A., 2005. Anthropogenic ocean acidification over the twenty-first century and its impact on calcifying organisms. Nat. 437, 681-686.

Pala, C., 2013. Giant Marine Reserves Pose Vast Challenges. Sci. 339, 640-641.

Podestá, G.P., Browder, J.A., Hoey, J.J., 1993. Exploring the association between swordfish catch rates and thermal fronts on U.S. longline grounds in the western North Atlantic. Cont. Shelf Res. 13, 253-277.

Polacheck, T., 2006. Tuna longline catch rates in the Indian Ocean: Did industrial fishing result in a $90 \%$ rapid decline in the abundance of large predatory species? Mar. Policy 30, 470-482.

Prince, E.D., Luo, J., Phillip Goodyear, C., Hoolihan, J.P., Snodgrass, D., Orbesen, E.S., Serafy, J.E., Ortiz, M., Schirripa, M.J., 2010. Ocean scale hypoxia-based habitat compression of Atlantic istiophorid billfishes. Fish. Oceanogr. 19, 448-462.

R Development Core Team, 2013. R: A Language and Environment for Statistical Computing. R Foundation and Statistical Computing, Vienna, Austria. http://www.Rproject.org.

Ravier, C., Fromentin, J.M., 2004. Are the long-term fluctuations in Atlantic bluefin tuna (Thunnus thynnus) population related to environmental changes? Fish. Oceanogr. 13, 145-160.

Reygondeau, G., Maury, O., Beaugrand, G., Fromentin, J.M., Fonteneau, A., Cury, P., 2012. Biogeography of tuna and billfish communities. J. of Biogeogr. 39, 114-129.

Rooker, J.R., Kitchens, L.L., Dance, M.A., Wells, R.J.D., Falterman, B., Comic, M., 2013. Spatial, Temporal and Habitat-Related Variation in Abundance of Pelagic Fishes in the Gulf of Mexico: Potential Implications of the Deepwater Horizon Oil Spill. PLoS ONE 8: e76080. DOI: 10.1371/journal.pone.0076080

Royer, T.C., Fromentin, J.M., Gaspar, P., 2004. Association between bluefin tuna schools and oceanic features in the western Mediterranean. Mar. Ecol. Prog. Ser. 269, 249-263.

Sagarminaga, Y., Arrizabalaga, H., 2010. Spatio-temporal distribution of albacore (Thunnus alalunga) catches in the northeastern Atlantic: relationship with the thermal environment. Fish. Oceanogr. 19, 121-134.

Sagarminaga, Y., Arrizabalaga, H., 2014. Relationship of Northeast Atlantic albacore juveniles with upper surface thermal and chlorophyll-a fronts. Deep-Sea Research Part II: Topical Studies in Oceanography. http://dx.doi.org/10.1016/j.dsr2.2013.11.006.

Salinger, M.J., Bell, J.D., Evans, K., Hobday, A.J., Allain, V., Brander, K., Dexter, P., 
Harrison, D.E., Hollowed, A.B., Lee, B., Stefanski, R., 2013. Climate and oceanic fisheries: recent observations and projections and future needs. Clim. Chang. 119, 213-221.

Schaefer, K., Fuller, D., Block, B., 2007. Movements, behavior, and habitat utilization of yellowfin tuna (Thunnus albacares) in the northeastern Pacific Ocean, ascertained through archival tag data. Mar. Biol. 152, 503-525.

Schaefer, K., Fuller, D., 2010. Vertical movements, behavior, and habitat of bigeye tuna (Thunnus obesus) in the equatorial eastern Pacific Ocean, ascertained from archival tag data. Mar. Biol. 157, 2625-2642.

Schaefer, K.M., Fuller, D.W., Aldana, G., 2014. Movements, behavior, and habitat utilization of yellowfin tuna (Thunnus albacares) in waters surrounding the Revillagigedo Islands Archipelago Biosphere Reserve, Mexico. Fish. Oceanogr. 23, 65-82.

Schick, R.S., Lutcavage, M.E., 2009. Inclusion of prey data improves prediction of bluefin tuna (Thunnus thynnus) distribution. Fish. Oceanogr. 18, 77-81.

Stramma, L., Prince, E.D., Schmidtko, S., Luo, J., Hoolihan, J.P., Visbeck, M., Wallace, D.W.R., Brandt, P., Körtzinger, A., 2012. Expansion of oxygen minimum zones may reduce available habitat for tropical pelagic fishes. Nat. Clim. Chang. 2, 33-37.

Sund, P.N., Blackburn, M., William, F., 1981. Tunas and their environment in the Pacific ocean: a review. Oceanogr. Mar. Biol. Ann. Rev. 19, 443-512.

Teo, S.L.H., Boustany, A., Dewar, H., Stokesbury, M.J.W., Weng, K.C., Beemer, S., Seitz, A.C., Farwell, C.J., Prince, E.D., Block, B.A., 2007. Annual migrations, diving behavior, and thermal biology of Atlantic bluefin tuna, Thunnus thynnus, on their Gulf of Mexico breeding grounds. Mar. Biol. 151, 1-18.

Teo, S.L.H., Block, B.A., 2010. Comparative Influence of Ocean Conditions on Yellowfin and Atlantic Bluefin Tuna Catch from Longlines in the Gulf of Mexico. Plos ONE 5, e10756.

van der Lingen, C.D., Hutchings, L., Merkle, D., van der Westhuizen, J.J., Nelson, J., 2001. Comparative spawning habitats of anchovy (Engraulis capensis) and sardine (Sardinops sagax) in the Southern Benguela Upwelling Ecosystem, in: Kruse, G.H., Bez, N., Booth, T., Dorn, M., Hills, S., Lipcius, R.N., Pelletier, D., Roy, C., Smith, S.J., Witherell, D. (Eds.), Spatial Processes and Management of Marine Populations. Fairbanks, AK: University of Alaska Sea Grant, AK-SG-01-1158 02; 2001, pp. 185209.

Walli, A., Teo, S.L.H., Boustany, A., Farwell, C.J., Williams, T., Dewar, H., Prince, E., 
Block, B.A., 2009. Seasonal Movements, Aggregations and Diving Behavior of Atlantic Bluefin Tuna (Thunnus thynnus) Revealed with Archival Tags. Plos ONE 4, e6151.

Wood, S.N., 2006. Generalized Additive Models; and introduction with R. Chapman and Hall/CRC, London.

Worm, B., Sandow, M., Oschlies, A., Lotze, H.K., Myers, R.A., 2005. Global patterns of predator diversity in the open oceans. Sci. 309, 1365-1369.

Worm, B., Tittensor, D.P., 2011. Range contraction in large pelagic predators. Proc. of the Natl. Acad. of Sci. 108, 11942-11947.

Young, J.W., Hunt, B., Cook, T., Llopiz, J., Hazen, E.L., Pethybridge, H., Ceccarelli, D., Lorrain, A., Olson, R.J., Allain, V., Menkes, C., Patterson, T., Nicol, S., Lehodey, P., Kloser, R., Arrizabalaga, H., Choy, C.A., 2014. The trophodynamics of marine top predators: current knowledge, recent advances and challenges. Deep Sea Res. Part II. This issue.

Zainuddin, M., Kiyofuji, H., Saitoh, K., Saitoh, S.I. 2006. Using multi-sensor satellite remote sensing and catch data to detect ocean hot spots for albacore (Thunnus alalunga) in the northwestern North Pacific. Deep Sea Res. Part II 53, 419-431.

\section{Tables}

Table 1: Percent deviance of $\log (\mathrm{CPUE})$ explained by each variable in univariate GAMs (each variable modelled separately). sbt: southern bluefin tuna (Thunnus maccoyii); bft: bluefin tuna (Thunnus thynnus); alb: albacore (Thunnus alalunga); bet: bigeye tuna (Thunnus obesus); yft: yellowfin tuna (Thunnus albacares); skj: skipjack tuna (Katsuwonus pelamis); temp5: temperature at $5 \mathrm{~m}$; temp100: temperature at $100 \mathrm{~m}$; sal: salinity; o2: oxygen; ssh: sea surface height anomaly; mld: mixed layer depth; ldchl: dissolved chlorophyll (log scale); lzoo: zooplankton concentration (log scale).

\begin{tabular}{lllllll}
\hline & sbt & bft & alb & bet & yft & skj \\
\hline stock & & 0.01 & 12.11 & 19.57 & 0.78 & 23.27 \\
year & 6.6 & 19.71 & 5.83 & 2.22 & 9.39 & 20.6 \\
season & 0.63 & 1.93 & 1.81 & 0.32 & 0.57 & 1.43 \\
temp5 & 37.55 & 11.55 & 14.55 & 11.7 & 32.23 & 6.39 \\
temp100 & 38.17 & 15.31 & 6.98 & 8.83 & 22.65 & 2.21 \\
sal & 16.87 & 4.17 & 8.48 & 1.33 & 1.65 & 9.33 \\
o2 & 35.23 & 16.3 & 21.68 & 14.6 & 31.19 & 9.49 \\
ssh & 27.84 & 21.94 & 0.75 & 6.25 & 4.61 & 14.17 \\
mld & 5 & 2.86 & 6.42 & 4.56 & 9.53 & 2.04 \\
ldchl & 2.92 & 8.31 & 4.49 & 1.5 & 4.09 & 5.67 \\
lzoo & 7.33 & 1.39 & 2.99 & 3.2 & 2.4 & 6.78 \\
\hline
\end{tabular}


Table 2: Results of full GAMs, with final Akaike Information Criteria (AIC) and the percent deviance explained by the model (\% Dev). For each variable retained in the final model, “df/edf” indicates the degrees of freedom (for fixed factors) or estimated degrees of freedom (for environmental variables). Empty cells indicate that the variable was not included in the final model. AIC' indicates the AIC value of the model when that particular variable was dropped during model selection. Dropping fixed factors or two way interactions was not tested if a higher order interaction was included in the model.

\begin{tabular}{|c|c|c|c|c|c|c|c|c|c|c|c|c|}
\hline & $\begin{array}{c}\text { Southern } \\
\text { bluefin }\end{array}$ & & $\begin{array}{l}\text { Atlantic } \\
\text { bluefin }\end{array}$ & & Albacore & & Bigeye & & Yellowfin & & Skipjack & \\
\hline & $\%$ Dev $=$ & 55.87 & $\% \mathrm{Dev}=$ & 52.29 & $\% \mathrm{Dev}=$ & 53.78 & $\% \mathrm{Dev}=$ & 45.35 & $\% \mathrm{Dev}=$ & .2 & $\%$ Dev= & 63.71 \\
\hline & $A I C=$ & 30812.9 & $\mathrm{AIC}=$ & 15169 & $A I C=$ & 203361.9 & $\mathrm{AIC}=$ & 206289.3 & $A I C=$ & 204616.1 & $\mathrm{AIC}=$ & 45158.3 \\
\hline Variable & df/edf & $\mathrm{AIC}^{\prime}$ & df/edf & $\mathrm{AlC}^{\prime}$ & df/edf & $\mathrm{AIC}^{\prime}$ & df/edf & AIC' & df/edf & $\mathrm{AIC}^{\prime}$ & $\mathrm{df} / \mathrm{edf}$ & $A I C^{\prime}$ \\
\hline stock & & & 1 & & 5 & & 3 & & 3 & & 3 & \\
\hline year & 40 & & 47 & & 47 & & 47 & & 47 & & 47 & \\
\hline season & 3 & & 3 & & 3 & & 3 & & 3 & & 3 & \\
\hline stock:year & & & 47 & & 192 & 209572.9 & 140 & & 140 & & 137 & \\
\hline stock:season & & & 3 & & 14 & 1264 & 9 & & 9 & & 9 & \\
\hline year:season & 119 & 30950.2 & 140 & & & & 141 & & 141 & & 141 & \\
\hline stock:year:season & & & 111 & 15184.6 & & & 420 & 206396.7 & 420 & 204976.7 & 386 & 45229.9 \\
\hline s(temp5) & 3.9 & 32022.1 & 3.87 & 15209.9 & 4 & 214533.2 & 3.99 & 217930.2 & 3.99 & 221981.0 & 3.97 & 45688.7 \\
\hline s(sal) & 3.95 & 31029.9 & 3.77 & 15217.7 & 3.77 & 203658.0 & 3.99 & 208181.1 & 3.99 & 206012.8 & 3.38 & 45475.1 \\
\hline $\mathrm{s}(\mathrm{ssh})$ & 3.98 & 31061.6 & 3.69 & 15337.1 & 4 & 211483.8 & 3.98 & 211367.2 & 3.97 & 204993.7 & 3.99 & 45461.4 \\
\hline $\mathrm{s}(\mathrm{mld})$ & 3.97 & 30953.5 & 1.4 & 15186.2 & 3.87 & 203547.0 & 4 & 208656.0 & 3.96 & 205617.9 & 2.53 & 45173.3 \\
\hline s(ldchl) & 3.83 & 31167.3 & 3.83 & 15221.7 & 3.95 & 204827.7 & 3.97 & 206851.9 & 3.97 & 205523.0 & 3.43 & 45163.7 \\
\hline
\end{tabular}

\section{Figure captions}

Figure 1. Pairwise scatter plots for all environmental variables. The lower diagonal set of plots shows the correlation coefficient (note that the font size of the correlation if proportional to its size) and the upper diagonal shows the scatter plots (see Table 1 legend for acronyms).

Figure 2. Full GAM predictions of habitat and observed log(CPUE) of tuna species. The coloured scale represents the predicted $\log (\mathrm{CPUE})$ at $1^{\circ} \mathrm{x} 1^{\circ}$ resolution, and the circles are proportional to observed average $\log (\mathrm{CPUE})$ at a $5^{\circ} \mathrm{x} 5^{\circ}$ resolution. 
Figure 3. Summary of quotient analyses, with species specific preference (green), tolerance (yellow) and avoidance (red) ranges for each environmental variable.

Figure 4. Response of species specific $\log (\mathrm{CPUE})$ to each environmental variable in the full GAMs (see table 1 legend for acronyms).

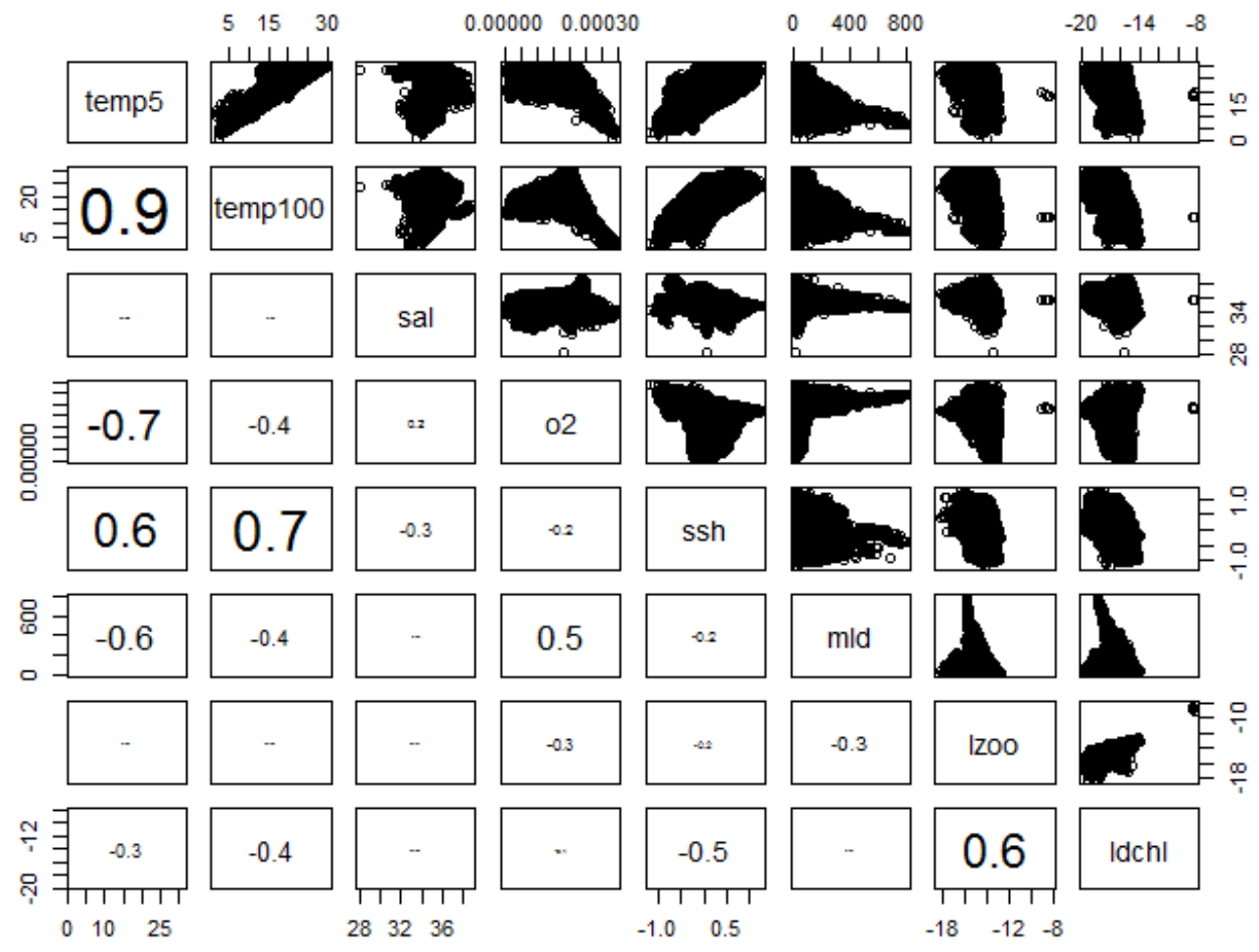

Figure 1. 

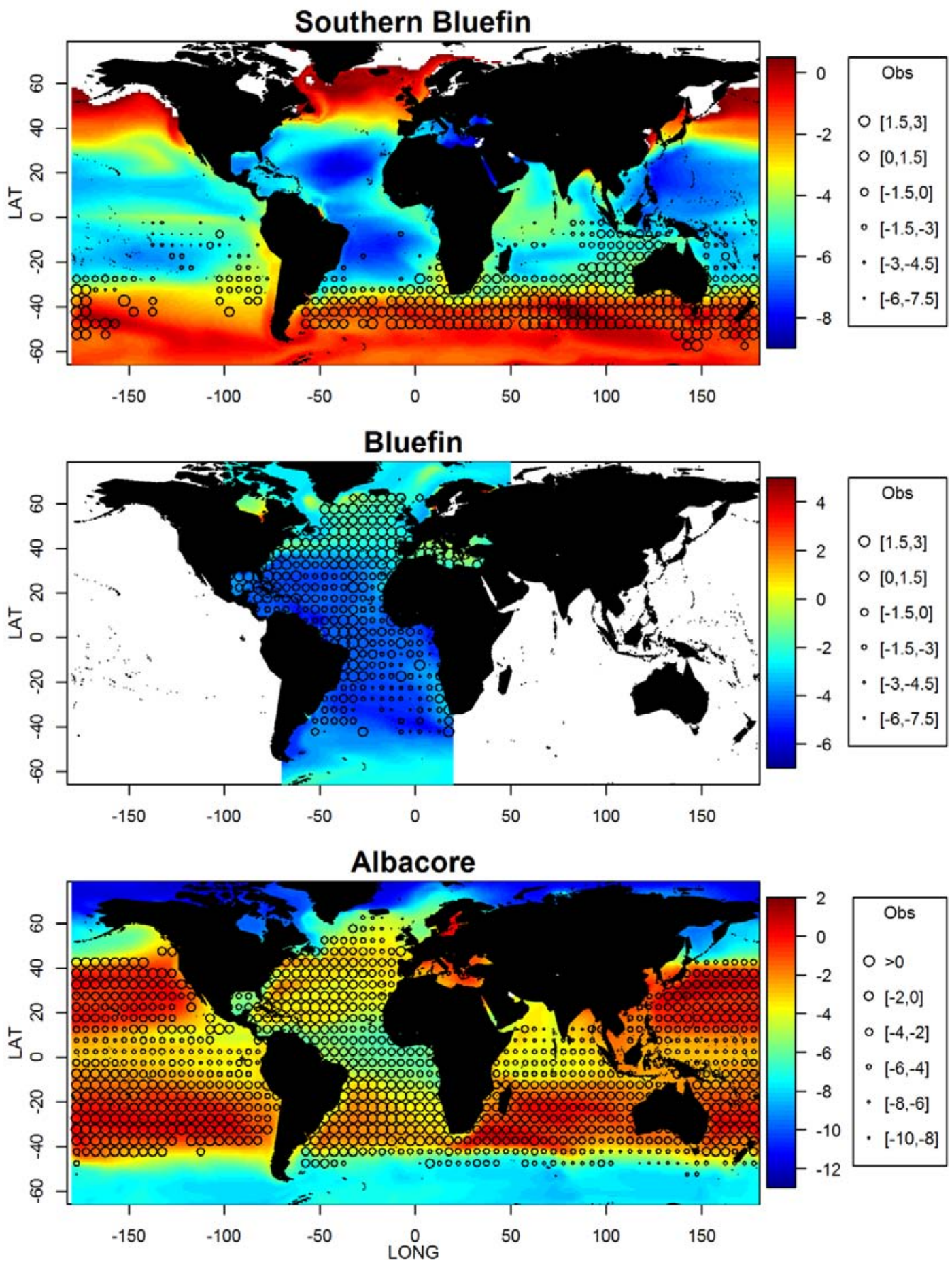

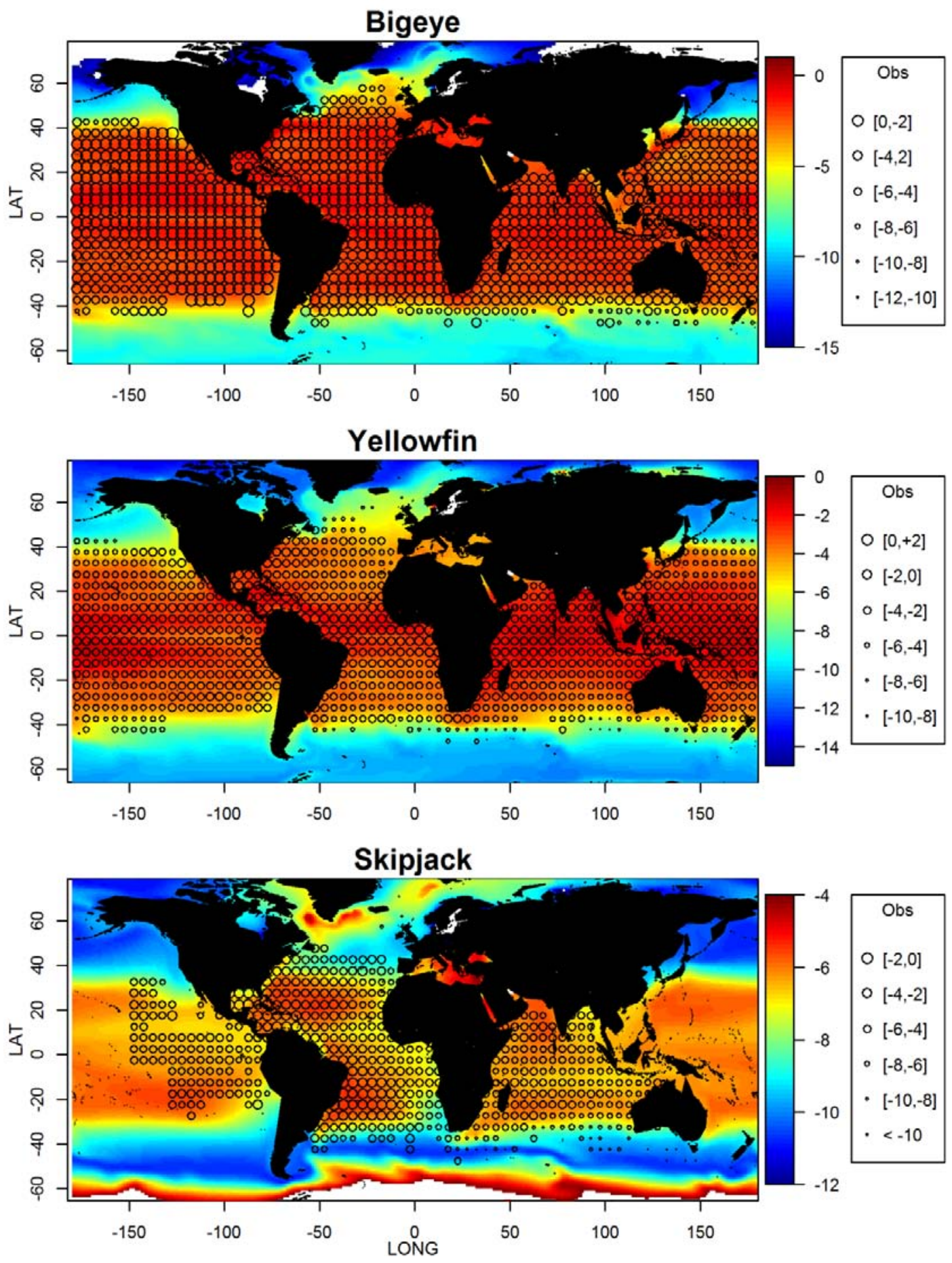

Figure 2. 


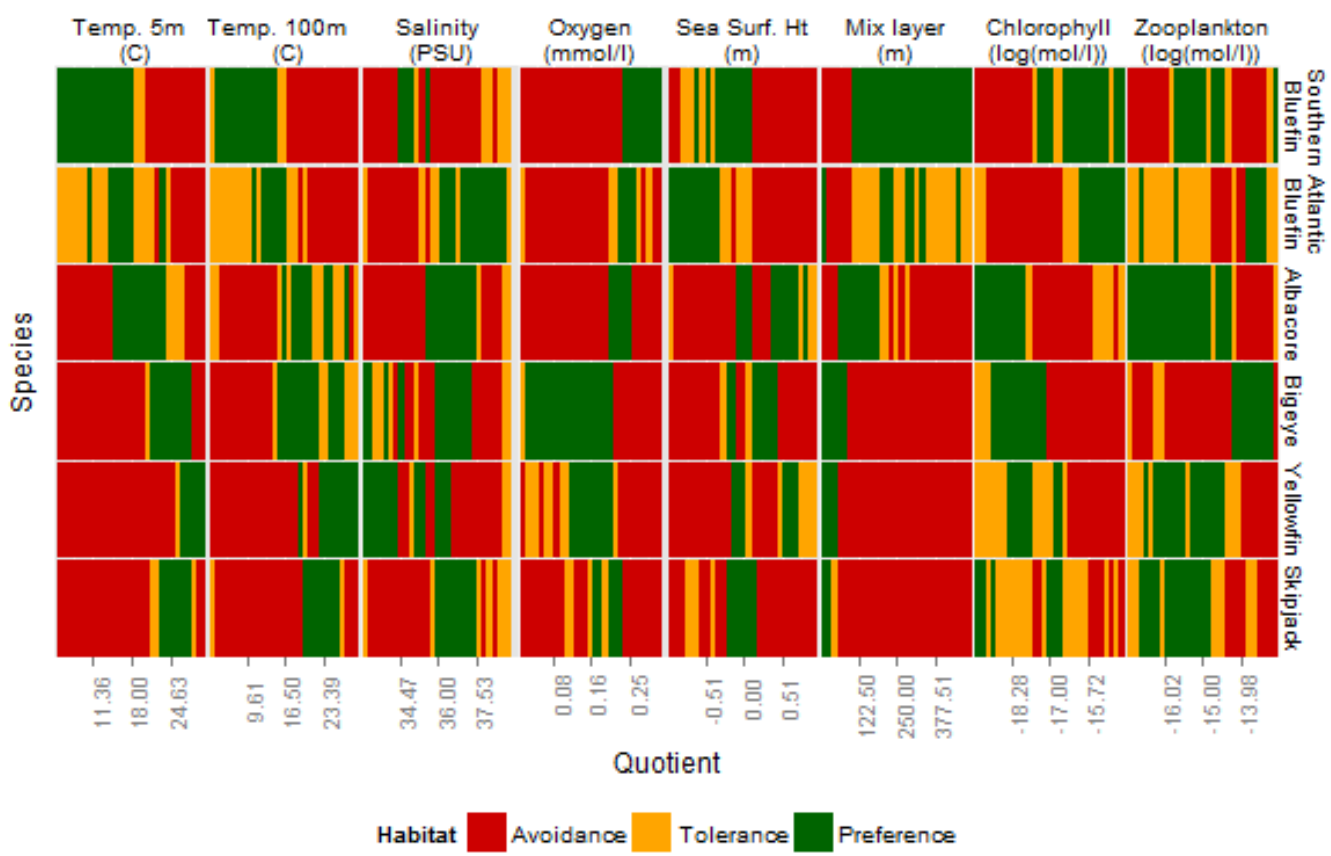

Figure 3. 


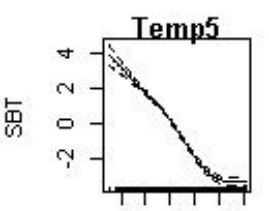

$5 \quad 15 \quad 25$
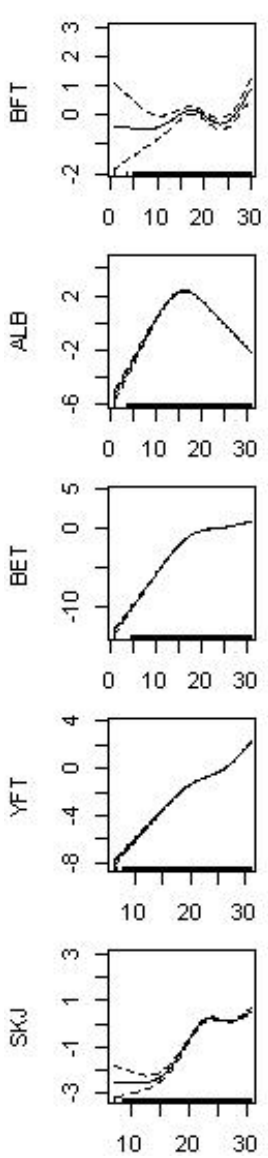
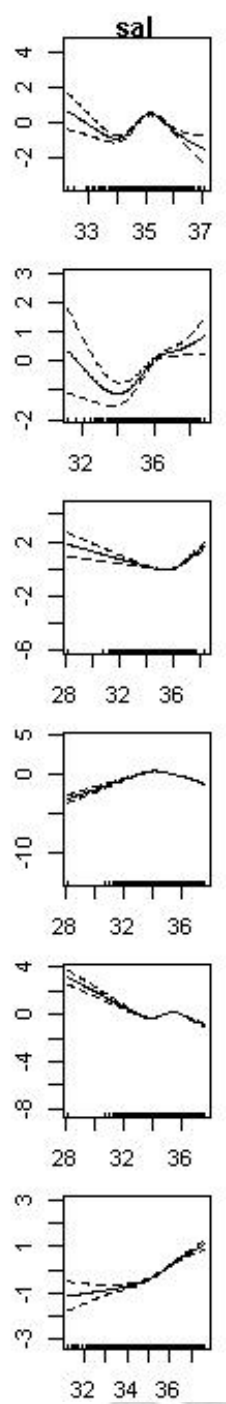
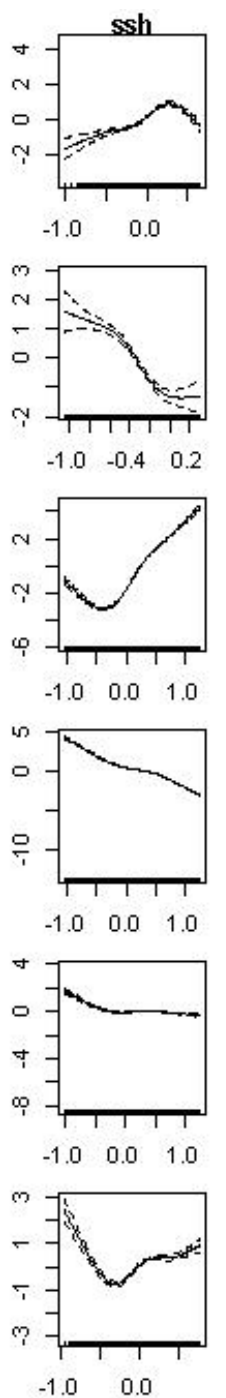
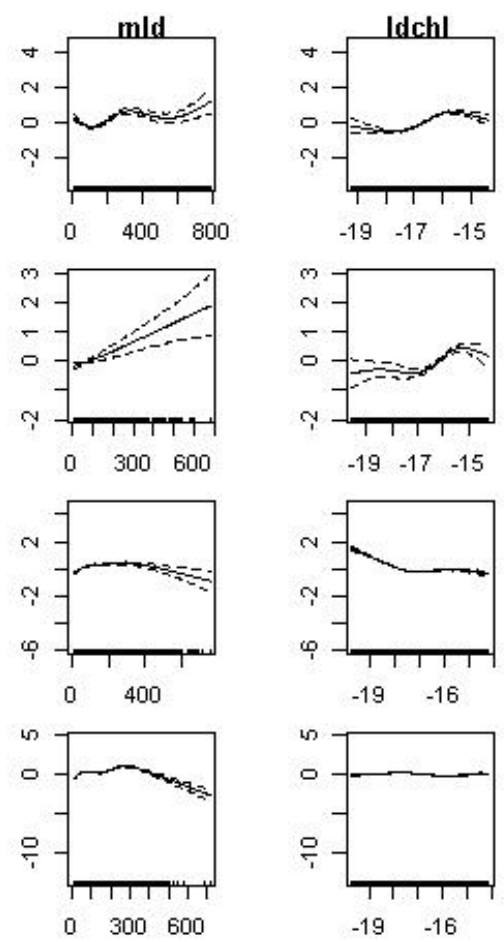

$-19 \quad-16$
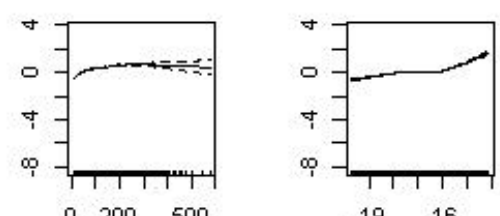

$-19 \quad-16$
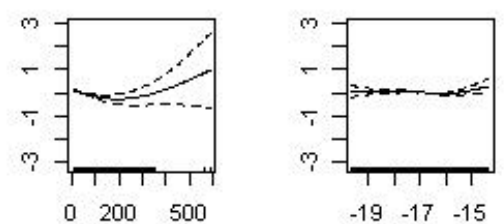

Figure 4.

a) Albacore tuna (Thunnus alalunga): 

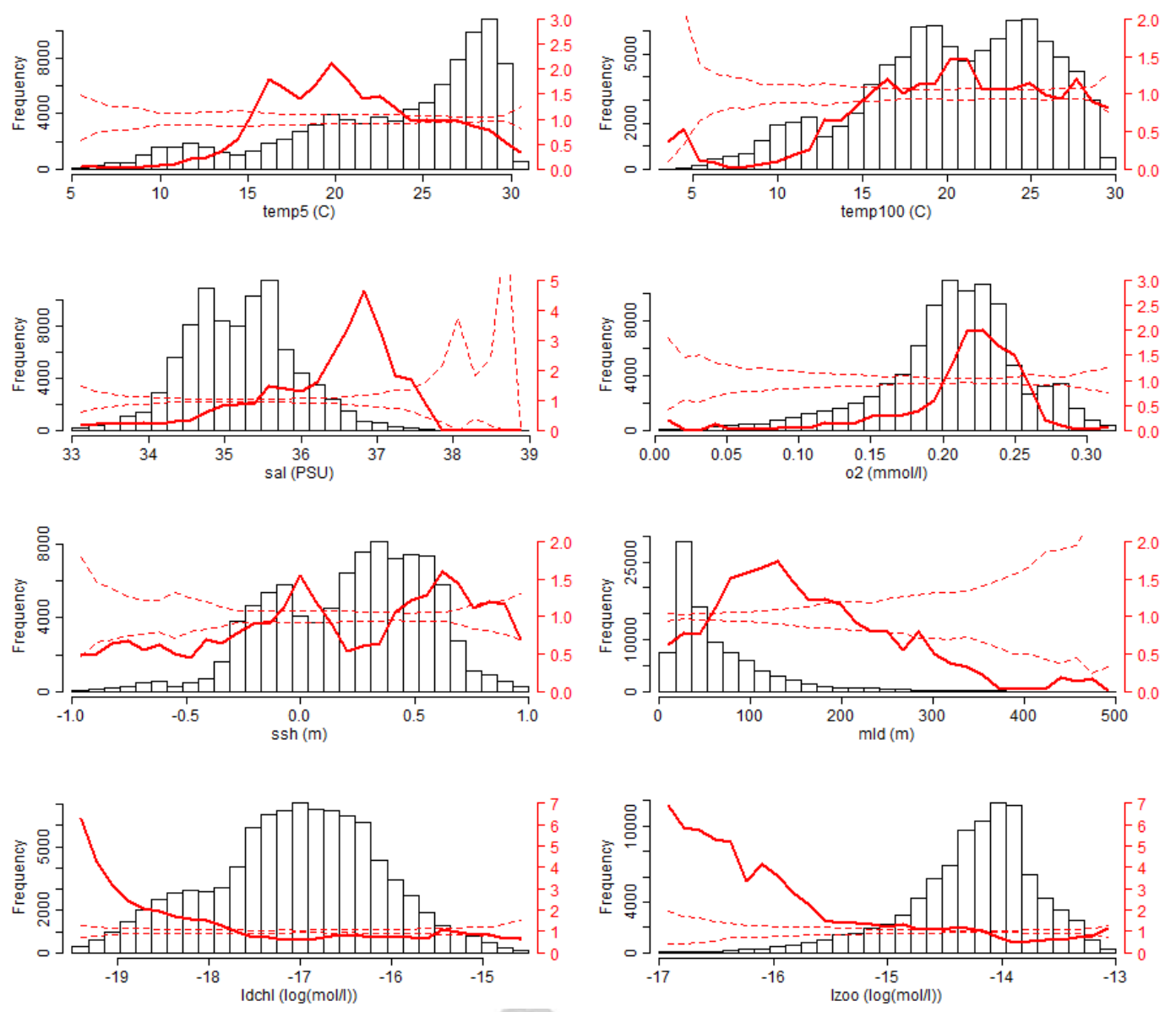

b) Bluefin tuna (Thunnus thynnus): 

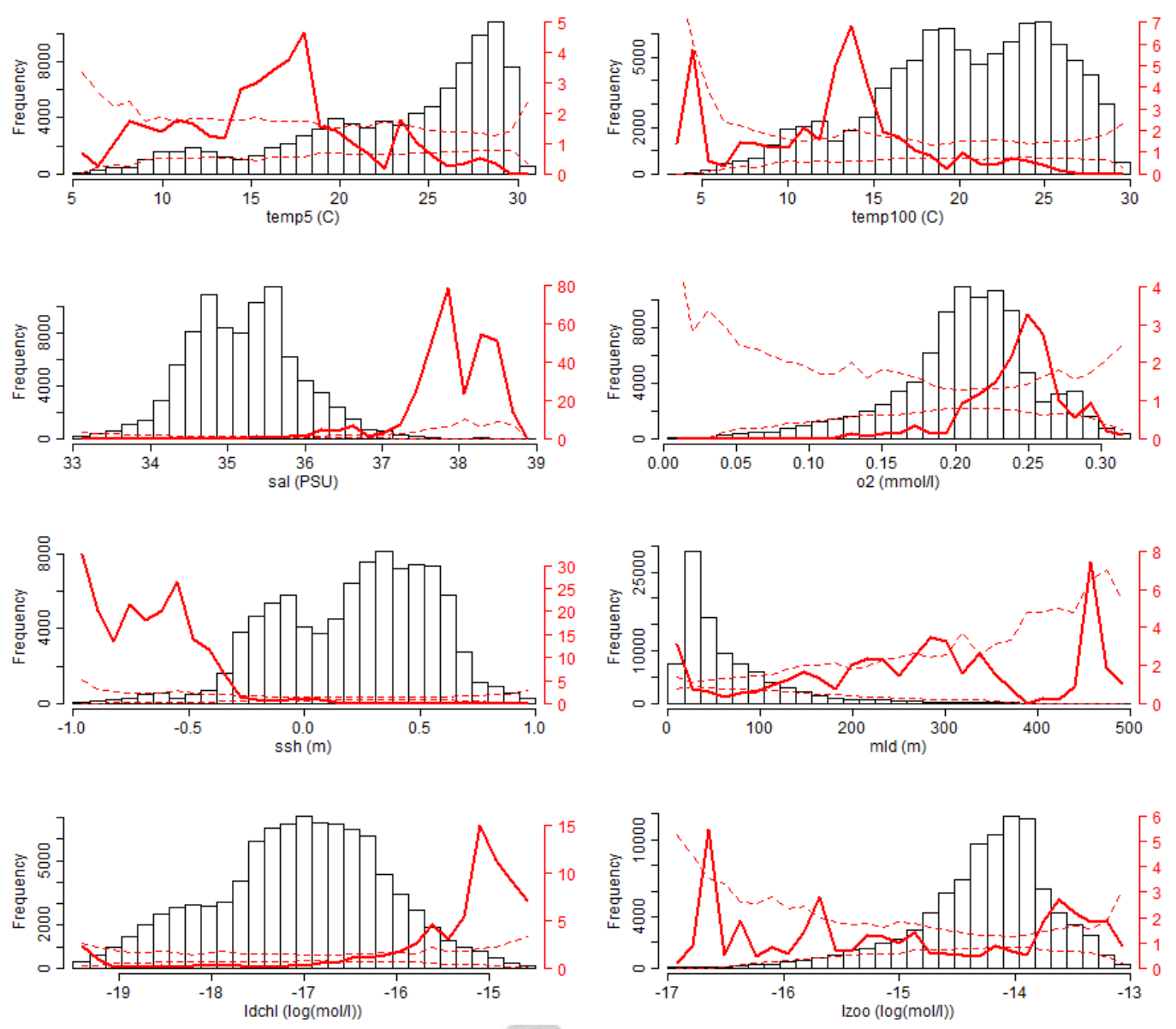

c) Southern bluefin tuna (Thunnus maccoyii): 

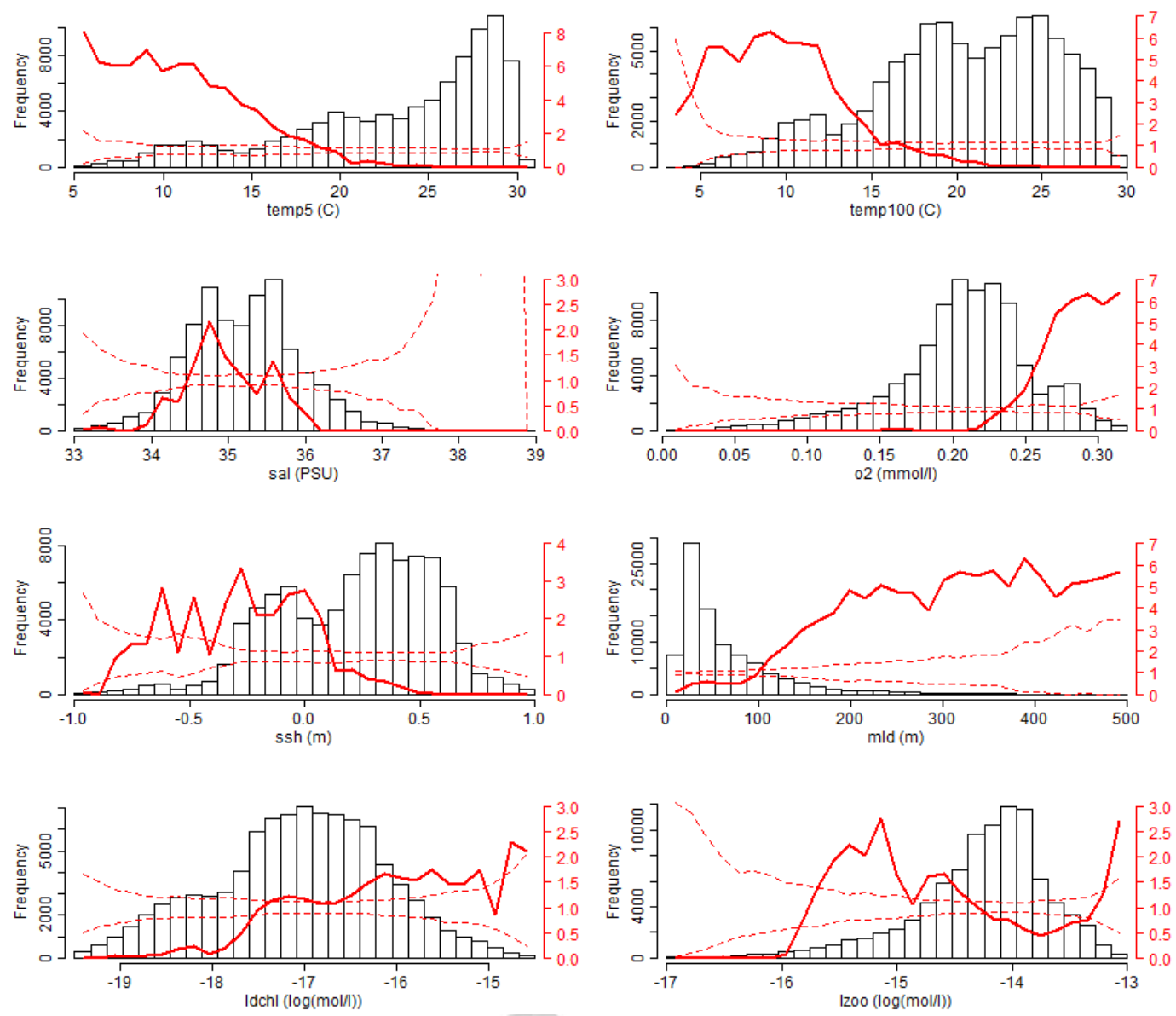

d) Bigeye tuna (Thunnus obesus): 

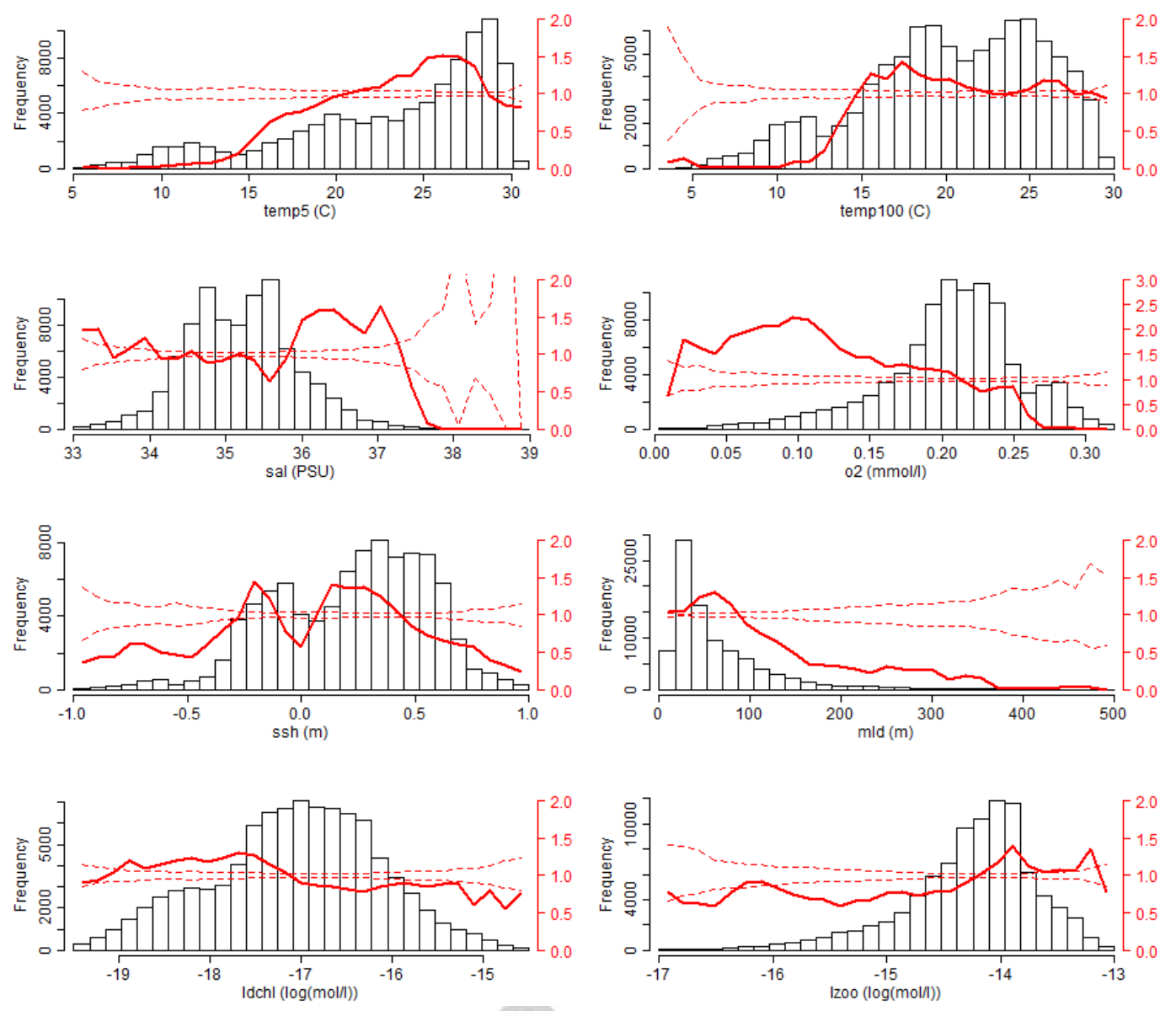

e) Yellowfin tuna (Thunnus albacares): 

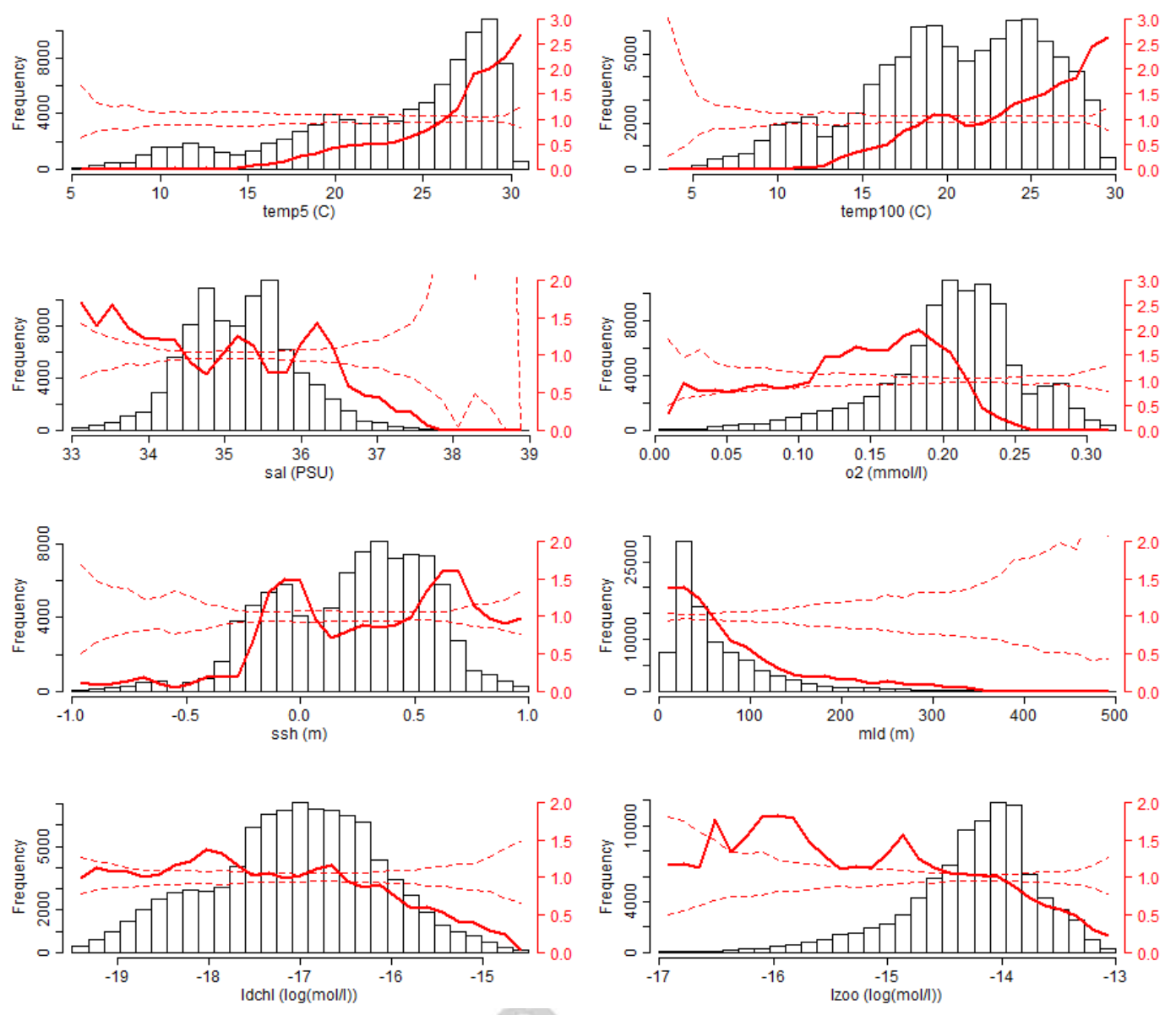

f) Skipjack tuna (Katsuwonus pelamis): 